Article

\title{
Graphite and Diamond Formation in the Carbide-Oxide-Carbonate Interactions (Experimental Modeling under Mantle P,T-Conditions)
}

\author{
Yuliya Bataleva ${ }^{1,2, *(1)}$, Yuri Palyanov ${ }^{1,2}$, Yuri Borzdov ${ }^{1,2}$, Ivan Novoselov ${ }^{1,2}$ and Oleg Bayukov ${ }^{3}$ \\ 1 Sobolev Institute of Geology and Mineralogy, Siberian Branch of Russian Academy of Sciences, Koptyug ave \\ 3, Novosibirsk 630090, Russia; palyanov@igm.nsc.ru (Y.P.); borzdov60@mail.ru (Y.B.); \\ i.novoselov@alumni.ru (I.N.) \\ 2 Department of Geology and Geophysics, Novosibirsk State University, Pirogova str 2, Novosibirsk 630090, \\ Russia \\ 3 Kirensky Institute of Physics, Siberian Branch of Russian Academy of Sciences, Akademgorodok 50, bld. 38, \\ Krasnoyarsk 660036, Russia; helg@iph.krasn.ru \\ * Correspondence: bataleva@igm.nsc.ru; Tel.: +7-3832-330-80-43
}

Received: 5 September 2018; Accepted: 8 November 2018; Published: 11 November 2018

\begin{abstract}
Experimental modeling of the formation of graphite and diamond as a result of carbide-fluid interactions was performed in the $\mathrm{Fe}_{3} \mathrm{C}-\mathrm{SiO}_{2}-\mathrm{Al}_{2} \mathrm{O}_{3}-(\mathrm{Mg}, \mathrm{Ca}) \mathrm{CO}_{3}$ systems at 6.3 and $7.5 \mathrm{GPa}$ and $1100-1650{ }^{\circ} \mathrm{C}$. In the experiments with $f \mathrm{O}_{2}$-gradient $\left(7.5 \mathrm{GPa}, 1250-1350{ }^{\circ} \mathrm{C}\right)$, graphite + magnesiowüstite + garnet \pm cohenite assemblage was formed. Graphite was produced through the redox interactions of carbide with carbonate or $\mathrm{CO}_{2}$ (reducing conditions), and redox reactions of magnesiowüstite and $\mathrm{CO}_{2}$ (oxidizing conditions). At $1450-1650{ }^{\circ} \mathrm{C}$, crystallization of graphite, garnet, magnesiowüstite and ferrospinel, as well as generation of $\mathrm{Fe}^{2+, 3+}$-rich carbonate-silicate melt occurred. This melt, saturated with carbon, acted as a medium of graphite crystallization and diamond growth on seeds. In the experiments without $f \mathrm{O}_{2}$-gradient $(6.3 \mathrm{GPa})$, decarbonation reactions with the formation of $\mathrm{CO}_{2}$-fluid and $\mathrm{Fe}, \mathrm{Mg}$,Ca-silicates, as well as $\mathrm{C}^{0}$-producing redox reactions of $\mathrm{CO}_{2}$-fluid with cohenite were simultaneously realized. As a result, graphite ( \pm diamond growth) was formed in assemblage with $\mathrm{Fe}^{2+}, \mathrm{Fe}^{3+}, \mathrm{Mg}$-silicates and magnetite $\left(1100-1200{ }^{\circ} \mathrm{C}\right)$, or with $\mathrm{Fe}^{3+}$-rich garnet and orthopyroxene $\left(1300-1500^{\circ} \mathrm{C}\right)$. It has been established that a potential mechanism for the crystallization of graphite or diamond growth is the oxidation of cohenite by $\mathrm{CO}_{2}$-fluid to $\mathrm{FeO}$ and $\mathrm{Fe}_{3} \mathrm{O}_{4}$, accompanied by the extraction of carbon from $\mathrm{Fe}_{3} \mathrm{C}$ and the corresponding reduction of $\mathrm{CO}_{2}$ to $\mathrm{C}^{0}$.
\end{abstract}

Keywords: cohenite; graphite; diamond; $\mathrm{CO}_{2}$ fluid; carbonate; garnet; experiment; high pressure; lithospheric mantle; metasomatism

\section{Introduction}

Establishing the specific features of the redox profile throughout the Earth's mantle with corresponding changes of structure, phase and chemical rocks compositions is one of the primary goals of modern mantle mineralogy and petrology. The oxidation state of mantle rocks may be defined by heterogeneous reactions between oxygen and iron- or carbon-bearing minerals $[1,2]$. Under redox conditions of the upper mantle, formation of metallic iron (or $\mathrm{Fe}-\mathrm{Ni}$ alloy) occurs below the metal precipitation curve, the position of which is defined by the oxygen fugacity $\left(f \mathrm{O}_{2}\right)$ at which Fe precipitates from mantle silicates, and the depth or pressure of metal precipitation line depends on bulk rock composition. Pressures of some metal precipitation reactions were established experimentally and theoretically [3-8], and it was predicted that, at depths greater than $250 \mathrm{~km}$ 
( $\mathrm{P} \geq 7 \mathrm{GPa}$ ), the Earth's mantle is reduced enough to become metal-saturated. More specifically, it was experimentally demonstrated [6] that pure metallic iron could be formed as a result of disproportionation reaction, where majoritic garnet acted as a sink for ferric iron, with $\mathrm{Fe}^{3+} / \Sigma \mathrm{Fe}$ ratios varying from $0.02-0.12(\sim 7 \mathrm{GPa})$ to $0.4(14 \mathrm{GPa})$. Besides the stabilization of $\mathrm{Fe}^{3+}$-bearing garnet species, presence of highly reduced metal-saturated mantle rocks at great depths has a number of petrologic consequences, affecting the behavior of redox-sensitive elements, e.g., carbon. Under these conditions, such carbon-bearing phases as carbides, diamond and graphite, as well as fluid [4,9-11], are stable. According to the data in $[4,9,10,12]$, under metal-saturated conditions in the depleted mantle (20-120 ppm C), carbon presents as a solution in metal and in the undepleted mantle (300-800 ppm C) it presents as carbides (Fe3C and Fe7C3), diamond and graphite. Presence of iron carbides at great depths is evidenced by inclusions in diamonds [13-17]. Recent experimental studies [18-20] show that iron carbide participates in the deep carbon cycle processes, involving redox graphite- and diamond-forming reactions, metasomatic interactions, generation of $\mathrm{Fe}-\mathrm{C}$-based melts and formation of ferrous and ferric silicates.

Studies on the deep carbon cycle [9,21-23] demonstrate that subduction is one of the main mechanisms of the transport of carbonate-bearing rocks, oxidized melts and fluids into the Earth's mantle. Discovery of xenoliths of strongly oxidized rocks with $f \mathrm{O}_{2} \sim \mathrm{FMQ}+1 \log$ unit $[5,24]$ evidences that part of the lithospheric mantle was subjected to the action of mobile metasomatic agents-carbonate melts or oxidized components of $\mathrm{C}-\mathrm{O}-\mathrm{H}$ fluid [2,25-28]. Subduction of crustal material into the mantle also enables redox interactions between oxidized (carbonate-oxide-silicate) species and reduced metal- or carbide-bearing rocks [7]. Possibility of this interaction is confirmed by data on inclusions in diamonds, varying in composition from highly reduced [13,29-31], to oxidized, including silicates and oxides [32-35], carbonates and pure $\mathrm{CO}_{2}$ [36,37]. Recently, the model of diamond-forming mixing process was proposed based on the complex study of the carbon isotopic compositions of sub-lithospheric diamonds and oxygen isotopic compositions of inclusions therein [38]. The relationship between $\delta^{13} \mathrm{C}$ and $\delta^{18} \mathrm{O}$ for Brazil diamonds suggests the diamond formation via interaction of slab-derived carbonate melt with reduced (carbide- or metal-bearing) mantle and confirms the presence of iron carbide phase in the deep mantle.

To date, carbide behavior under mantle pressures and temperatures has been experimentally investigated in $\mathrm{Fe}-\mathrm{C}, \mathrm{Fe}-\mathrm{Ni}-\mathrm{C}, \mathrm{Fe}-\mathrm{C}-\mathrm{S}$ and $\mathrm{Fe}-\mathrm{Ni}-\mathrm{C}-\mathrm{S}$ systems $[12,19,39-42]$, as well as in more complex systems, modeling carbide interaction with mantle minerals-oxides [43], sulfides [20] and carbonates [18]. However, there is a lack of studies devoted to the modeling of the iron carbide behavior in the presence of fluid, under silicate mantle $\mathrm{P}, \mathrm{T}, \mathrm{x}$-conditions, which can be valuable sources of new data on mantle oxygen fugacity $\left(f \mathrm{O}_{2}\right)$ patterns, potential graphite/diamond-producing processes and characteristic features of the formation of Fe-bearing silicates as well as carbonate-silicate melts.

The main goals of the present study, which can be achieved by high-pressure experiments, were: (1) to model carbide-fluid reactions in the carbide-oxide-carbonate systems at the pressures close to metal-precipitation line (6.3 and 7.5 GPa); (2) to reconstruct the graphite- and diamond-forming reactions, in which carbide and carbonate are both sources of carbon; and (3) to study the conditions of formation of ferric and ferrous silicates and Fe-rich carbonate-silicate melts under lithospheric mantle P,T-parameters.

\section{Materials and Methods}

Experiments were carried out using a multi-anvil high-pressure apparatus of a "split-sphere" type (BARS) [44] in the $\mathrm{Fe}_{3} \mathrm{C}-\mathrm{SiO}_{2}-\mathrm{Al}_{2} \mathrm{O}_{3}-(\mathrm{Mg}, \mathrm{Ca}) \mathrm{CO}_{3}$ (carbide-oxide-carbonate) systems at the pressures of 6.3 and $7.5 \mathrm{GPa}$, in the temperature range of $1100-1650{ }^{\circ} \mathrm{C}$, and a run duration from 8 to $40 \mathrm{~h}$. Details on high pressure cell design as well as the calibration data were published previously $[45,46]$. To model carbide-fluid interactions, oxide-carbonate mixtures were used as a $\mathrm{CO}_{2}$-fluid source due to the decarbonation reactions in high pressure-high temperature experiments. Silicates, formed via decarbonation, acted as a sink for oxidized iron. Initial reagents were synthetic $\mathrm{Fe}_{3} \mathrm{C}$ (cohenite), 
$\mathrm{SiO}_{2}, \mathrm{Al}_{2} \mathrm{O}_{3}$ (99.99\% pure) as well as natural specimens of magnesite and dolomite $(<0.05 \mathrm{wt} \%$ of impurities, Satka deposit, Urals, Russia). Cohenite was preliminarily synthesized in a $\mathrm{Fe}-\mathrm{C}$ system at $\mathrm{P}=5.7 \mathrm{GPa}$ and $\mathrm{T}=1450{ }^{\circ} \mathrm{C}$, and thoroughly analyzed by X-ray powder diffraction (Stoe IPDS-2T diffractometer, STOE, Darmstadt, Germany). The initial mixture of the carbonates had a bulk composition of $\mathrm{Mg}_{0.9} \mathrm{Ca}_{0.1} \mathrm{CO}_{3}$. Proportions of initial materials (Tables 1 and 2) were chosen to produce $\mathrm{CO}_{2}$-dominated fluid and garnet via decarbonation reaction (Reaction (1)) and to realize further interaction of these phases with cohenite (Reaction (2)):

$$
\begin{gathered}
3 \mathrm{SiO}_{2}+\mathrm{Al}_{2} \mathrm{O}_{3}+3(\mathrm{Mg}, \mathrm{Ca}) \mathrm{CO}_{3} \rightarrow(\mathrm{Mg}, \mathrm{Ca})_{3} \mathrm{Al}_{2} \mathrm{Si}_{3} \mathrm{O}_{12}+3 \mathrm{CO}_{2} \\
2 \mathrm{Fe}_{3} \mathrm{C}+3 \mathrm{CO}_{2} \rightarrow 6 \mathrm{FeO}_{\text {in silicates }}+5 \mathrm{C}^{0}
\end{gathered}
$$

Table 1. Mass proportions of starting materials.

\begin{tabular}{ccccccc}
\hline \multirow{2}{*}{ Experimental Series } & \multirow{2}{*}{$\mathbf{P}, \mathbf{G P a}$} & \multicolumn{5}{c}{ Starting Materials, $\mathbf{m g}$} \\
\cline { 3 - 6 } & & $\mathbf{F e}_{\mathbf{3}} \mathbf{C}$ & $\mathbf{S i O}_{\mathbf{2}}$ & $\mathbf{A l}_{\mathbf{2}} \mathbf{O}_{\mathbf{3}}$ & $\mathbf{M g C O}_{\mathbf{3}}$ & $\mathbf{C a M g}\left(\mathbf{C O}_{3}\right)_{\mathbf{2}}$ \\
\hline “Mixture-type" & 6.3 & 24.6 & 29.5 & 16.8 & 11.0 & 2.8 \\
\hline "Sandwich-type" & 7.5 & 72.2 & 33.7 & 18.9 & 37.8 & 9.5 \\
\hline
\end{tabular}

\begin{tabular}{|c|c|c|c|c|c|c|c|c|c|c|c|c|c|c|c|}
\hline \multirow{2}{*}{$\begin{array}{l}\text { Experimental } \\
\text { Series }\end{array}$} & \multirow{2}{*}{ P, GPa } & \multicolumn{7}{|c|}{ Mass Concentrations, wt \% } & \multicolumn{7}{|c|}{ Molar Concentrations, mol \% } \\
\hline & & Si & Al & $\mathrm{Fe}$ & $\mathrm{Mg}$ & $\mathrm{Ca}$ & $\mathrm{C}$ & O & Si & Al & $\mathrm{Fe}$ & $\mathrm{Mg}$ & $\mathrm{Ca}$ & C & $\mathrm{O}$ \\
\hline "Mixture-type" & 6.3 & 15.6 & 10.1 & 26.1 & 4.5 & 1.5 & 4.6 & 37.6 & 12.8 & 8.6 & 10.7 & 4.3 & 0.9 & 8.7 & 54.0 \\
\hline "Sandwich-type" & 7.5 & 8.6 & 5.5 & 36.7 & 7.4 & 2.5 & 7.0 & 32.3 & 7.4 & 4.9 & 15.8 & 7.4 & 1.5 & 14.2 & 48.8 \\
\hline
\end{tabular}

Table 2. Bulk compositions of the carbide-oxide-carbonate systems.

Two different methodical approaches were used for experiments at 6.3 and 7.5 GPa. The experimental technique and methodical approach for the series at $7.5 \mathrm{GPa}$ (so-called "sandwich"-type experiments) was developed and described in detail in [47]. The elaborated technique made it possible to perform experimental modeling of fluid- and melt-generating processes as well as of redox interaction of these fluids and melts with Fe-rich mantle minerals (ilmenite, chromite, wüstite, $\mathrm{Fe}^{0}$, pyrrhotite, and cohenite) under P,T-conditions of the lithospheric mantle [18,47-50]. Using this technique ensures the formation of a redox gradient by separation of the reaction volume of ampoules into peripheral (carbonate-oxide, i.e., oxidized) and central (containing an iron concentrator, i.e., reduced) parts (Figure 1a). This enables decarbonation reactions and generation of Fe-enriched carbonate-bearing melts as well as $\mathrm{C}^{0}$-producing redox interaction of the newly formed fluid or melt with the Fe-Concentrating phases under mantle P,T-parameters. It should be emphasized that "sandwich"-type experiments were developed to study specific reactions on a base of reaction zoning of samples, without reaching equilibrium conditions.

When assembling, an ampoule made of the pressed mixture of oxides and carbonates was placed into a Pt capsule (6 mm in outer diameter). A pellet made of pressed $\mathrm{Fe}_{3} \mathrm{C}$ was mounted in the center of this ampoule. Therefore, the iron-bearing phase was separated from the Pt-capsule. This methodical approach guarantees minimal iron loss, when even runs at $1650{ }^{\circ} \mathrm{C}$ and $7.5 \mathrm{GPa}$ are characterized by Fe loss about 1.0-1.2 wt \%, which is confirmed by analysis of Pt-capsule material after experiments and by the mass balance calculations. When assembling, synthetic diamond seed crystals of the cuboctahedral shape ( $\sim .5 \mathrm{~mm}$ in size) were placed in the carbonate-oxide ampoule (Figure 1a) to estimate whether the redox conditions in the reaction ampoules correspond to the stability field of diamond and to evaluate the possibility of diamond growth. 

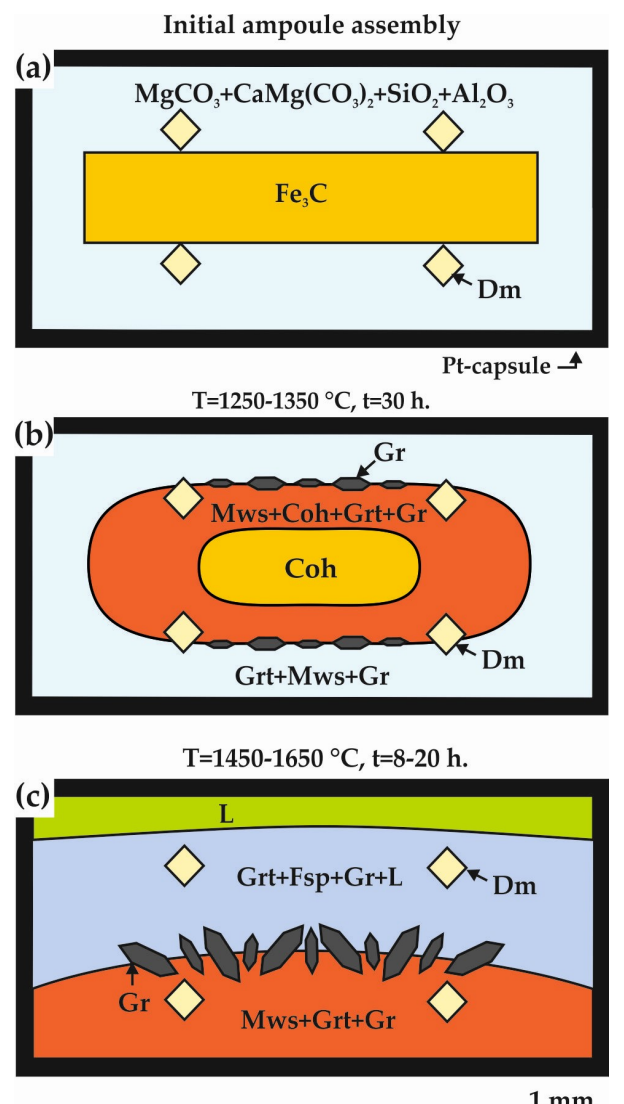

Figure 1. Schemes of carbide-oxide-carbonate interaction after "sandwich-type" experiments $\left(\mathrm{Fe}_{3} \mathrm{C}-\mathrm{Al}_{2} \mathrm{O}_{3}-\mathrm{SiO}_{2}-(\mathrm{Mg}, \mathrm{Ca}) \mathrm{CO}_{3}\right.$ system, $\left.\mathrm{P}=7.5 \mathrm{GPa}\right)$ : (a) initial ampoule assembly (before experiments); (b) samples after experiments at $1250-1350{ }^{\circ} \mathrm{C}, \mathrm{t}=30 \mathrm{~h}$; and (c) samples after experiments at 1450-1650 ${ }^{\circ} \mathrm{C}, \mathrm{t}=8-20 \mathrm{~h}$. Grt, garnet; Coh, cohenite; Mws, magnesiowustite; Fsp, ferrospinel; Gr, graphite; L, carbonate-silicate melt; Dm, diamond seeds.

The methodical approach used for the series of experiments in carbide-oxide-carbonate system at 6.3 GPa (so-called "mixture"-type experiments) was described in detail in [43]. Even though Pt is the optimal capsule material for experiments under high pressures and high temperatures, it cannot be used for Fe-bearing systems if there is a direct contact of Pt with phases of iron. Considering our previous experience in a field of carbide-involving experiments under mantle P,T-conditions [39,43], we used graphite as appropriate capsule material. These graphite capsules set the upper limit of the oxygen fugacity values in samples close to the $\mathrm{C}-\mathrm{CO}$ buffer equilibrium [47]. Starting materials, placed in graphite capsules, were powdered (particle size 10-20 $\mu \mathrm{m}$ ) and thoroughly homogenized. It should be noted that some part of the iron carbide was added into charge as relatively large crystals $(300-400 \mu \mathrm{m})$ to enable the processes of the carbide-oxide, carbide-carbonate and carbide-silicate interactions. For this reason, a small excess of iron carbide relative to the other reagents of Reaction (1) was created. Diamond seed crystals of cuboctahedral habit ( $500 \mu \mathrm{m}$ in size) were placed into the ampoules, to evaluate the possibility of diamond growth under conditions of the experiments.

We should separately emphasize the problem of the oxygen fugacity buffering of the samples in the present research. Iron carbide and $\mathrm{CO}_{2}$ fluid are extremely $f \mathrm{O}_{2}$-contrast, with $\Delta f \mathrm{O}_{2}$ of about $5 \log$ units. When modeling carbide-fluid reactions, which can occur as a result of subduction of oxidized material in the deep reduced mantle, it is inappropriate to use outer buffer that will set $f \mathrm{O}_{2}$ values at IW level. If this were done, $\mathrm{CO}_{2}$ fluid, generated as a result of decarbonation reactions, would be immediately reduced to form elemental carbon without participation of iron carbide. Thus, in the "sandwich"-type experiments, we used excess of cohenite to model reduced conditions in the central part of the sample and, in "mixture"-type experiments, we used outer buffer-graphite capsules, 
setting upper limit of $f \mathrm{O}_{2}$ values close to $\mathrm{C}-\mathrm{CO}$ (and FMQ) buffer, which are believed to be average upper mantle values.

The chemical composition of final phases was analyzed by energy dispersive spectroscopy (Tescan MIRA3 LMU scanning electron microscope, TESCAN, Brno, Czech Republic) and microprobe (WDS) analysis (Camebax-micro analyzer, CAMECA, Gennevilliers, France).

Microprobe analyses of silicates, oxides, and carbides were performed at an accelerating voltage of $20 \mathrm{kV}$, a beam current of $20 \mathrm{nA}$, a counting time of $10 \mathrm{~s}$ for each analytical line, and electron beam diameter of 2-4 $\mu \mathrm{m}$. The electron beam diameter of 20-100 $\mu \mathrm{m}$ was used when studying the composition of microdendrites of quenched metal-carbon melt. Quantitative analysis (both microprobe and energy dispersive spectroscopy) of carbon performed using mineral standards of cohenite, calcite and magnesite. Polished samples and standards for microprobe were coated with carbon; samples for energy dispersive spectroscopy were coated with carbon for first series of analyses, and with chromium for second series of ones. The phase relationships were studied by scanning electron microscopy. Analytical studies mentioned above were performed at the Center for Collective Use of Multi-element and Isotopic Analysis of the Siberian Branch of the Russian Academy of Sciences. Analysis of the composition of iron-bearing phases and valence state of iron therein was performed using Mössbauer spectroscopy. Measurements were carried out at room temperature on a MS-1104Em spectrometer (Cordon, Rostov on Don, Russia) with a Co57(Cr) source and a powdered absorber with a thickness of $1-5 \mathrm{mg} / \mathrm{cm}^{2}$. The methodology of measurements and analysis of Mössbauer spectra was described in detail in [51] (and Supplementary Information therein).

\section{Results}

\subsection{Experimental Results in the Carbide-Oxide-Carbonate System at the Pressure of $7.5 \mathrm{GPa}$} ("Sandwich"-Type Experiments with $\mathrm{fO}_{2}$-Gradient)

The results of experiments are shown in Table 3 and Figure 1. At relatively low temperatures $\left(1250-1350{ }^{\circ} \mathrm{C}\right)$, reduced central parts of samples are presented by cohenite lenses (Figure 1b), surrounded by reaction zones (Figure 2a) of cohenite, magnesiowüstite, garnet and unevenly distributed graphite. The oxidized peripheral parts of samples are presented by garnet + magnesiowüstite + graphite assemblage. Initial growth patterns on (111) and (100) faces of diamond on seeds is established by SEM (Figure 2c). The compositions of the final phases from different zones of samples, established by microprobe analysis and Mössbauer spectroscopy, are shown in Tables 4 and 5 .

Table 3. Results of experiments in the carbide-oxide-carbonate systems at 6.3 and 7.5 GPa.

\begin{tabular}{|c|c|c|c|c|c|}
\hline Run N & $\mathrm{P}, \mathrm{GPa}$ & $\mathrm{T},{ }^{\circ} \mathrm{C}$ & $t, h$ & Final Phases & Diamond Growth on Seeds \\
\hline \multicolumn{6}{|c|}{ "Mixture-type" experiments } \\
\hline CG-01 & 6.3 & 1100 & 40 & Grt, Opx, Mgt, Cor, Co, Fpc, Gr & - \\
\hline CG-02 & 6.3 & 1200 & 30 & Grt, Opx, Mgt, Cor, Co, Fpc, Gr & - \\
\hline CG-03 & 6.3 & 1300 & 20 & Grt, Opx, Gr, Mgt & - \\
\hline CG-04 & 6.3 & 1400 & 20 & Grt, Opx, Gr & - \\
\hline CG-05 & 6.3 & 1500 & 20 & Grt, Opx, Gr & + \\
\hline \multicolumn{6}{|c|}{ "Sandwich-type" experiments } \\
\hline ST-01 & 7.5 & 1250 & 30 & Coh, Grt, Mws, Gr & + \\
\hline ST-02 & 7.5 & 1350 & 20 & Coh, Grt, Mws, Gr & + \\
\hline ST-03 & 7.5 & 1450 & 20 & Grt, Mws, Fsp, Gr, $\mathrm{L}_{\text {carb-sil }}$ & + \\
\hline ST-04 & 7.5 & 1550 & 20 & Grt, Mws, Fsp, Gr, L $\mathrm{L}_{\text {carb-sil }}$ & + \\
\hline ST-05 & 7.5 & 1650 & 8 & Grt, Mws, Fsp, Gr, L $\mathrm{L}_{\text {carb-sil }}$ & + \\
\hline
\end{tabular}

Grt, garnet, Opx, orthopyroxene, Mgt, magnetite, Fpc, ferropericlase, Coh, cohenite, Cor, corundum, $\mathrm{Fe}-\mathrm{C}_{\text {melt, }}$ metal-carbon melt, $\mathrm{Co}$, coesite, Gr, graphite, Fsp, ferrospinel, Mws, magnesiowüstite, $\mathrm{L}_{\text {carb-sil }}$, carbonate-silicate melt. 

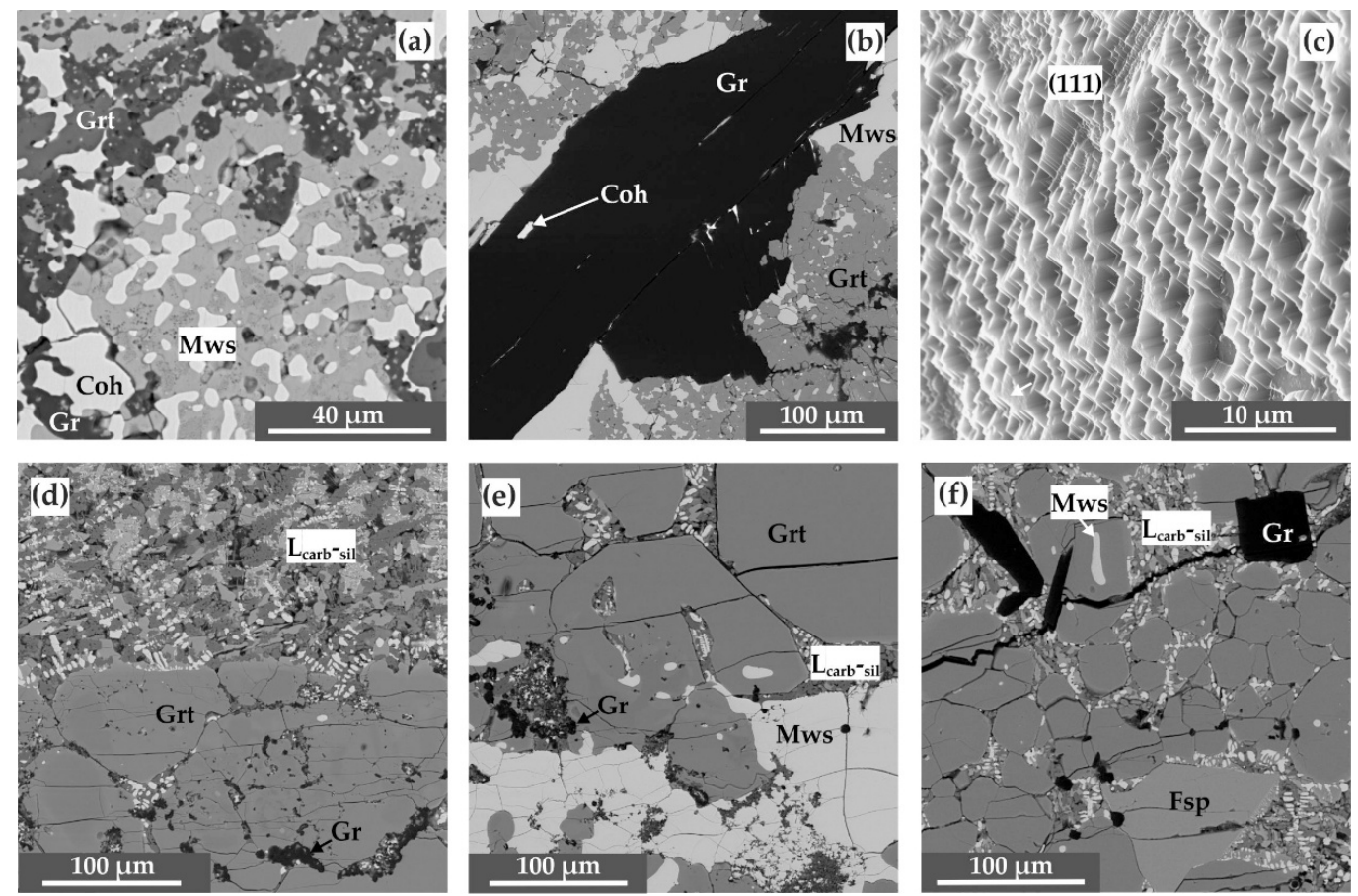

Figure 2. SEM-micrographs (BSE-regime) of polished fragments of the samples ("sandwich"-type experiments, $7.5 \mathrm{GPa}$ ): (a) cohenite, magnesiowustite, garnet and graphite assemblage (reduced part of the sample, $1250{ }^{\circ} \mathrm{C}$ ); (b) large graphite crystal with inclusions of cohenite and magnesiowustite, in a garnet + magnesiowustite + graphite aggregate $\left(1550{ }^{\circ} \mathrm{C}\right) ;(\mathrm{c})$ : growth patterns at $(111)$ face of the diamond seed $\left(1350^{\circ} \mathrm{C}\right) ;(\mathbf{d})$ garnet and graphite in the quenched carbonate-silicate melt $\left(1550{ }^{\circ} \mathrm{C}\right)$; (e) garnet in the quenched carbonate-silicate melt, at the contact with magnesiowustite + garnet + graphite polycrystalline aggregate $\left(1450^{\circ} \mathrm{C}\right)$; and (f) garnet, graphite and ferrospinel crystals in the quenched carbonate-silicate melt $\left(1550^{\circ} \mathrm{C}\right)$; Grt, garnet; Coh, cohenite; Mws, magnesiowüstite; Fsp, ferrospinel; Gr, graphite; $\mathrm{L}_{\text {carb-sil }}$, carbonate-silicate melt.

Table 4. Average compositions of silicates and oxides in the carbide-oxide-carbonate system ("sandwich-type" experiments) at 7.5 GPa, according to microprobe analysis.

\begin{tabular}{|c|c|c|c|c|c|c|c|c|c|c|c|}
\hline \multirow{2}{*}{ Run N } & \multirow{2}{*}{$\mathrm{T},{ }^{\circ} \mathrm{C}$} & \multirow{2}{*}{ Phase } & \multirow{2}{*}{$\mathbf{N}_{\mathrm{A}}$} & \multicolumn{8}{|c|}{ Mass Concentrations, wt \% } \\
\hline & & & & $\mathrm{SiO}_{2}$ & $\mathrm{Al}_{2} \mathrm{O}_{3}$ & $\mathrm{FeO}$ & $\mathrm{FeO} *$ & $\mathrm{Fe}_{2} \mathrm{O}_{3} *$ & $\mathrm{MgO}$ & $\mathrm{CaO}$ & Total \\
\hline \multirow{4}{*}{ ST-01 } & \multirow{4}{*}{1250} & Grt $^{P}$ & 14 & $41.6(7)$ & $23.1(5)$ & $8.9(8)$ & 9 & - & $16.9(5)$ & $9.5(4)$ & 100.0 \\
\hline & & Mws $^{P}$ & 16 & - & - & $89.7(7)$ & 84 & 6 & $9.5(8)$ & $0.33(6)$ & 99.6 \\
\hline & & $\mathrm{Grt}^{\mathrm{C}}$ & 15 & $40.9(3)$ & $21.8(1)$ & $13.4(3)$ & 13 & - & $15.2(3)$ & $8.5(4)$ & 99.8 \\
\hline & & Mws ${ }^{C}$ & 14 & - & - & $94.7(3)$ & 95 & - & $4.6(2)$ & $0.03(1)$ & 99.4 \\
\hline \multirow{4}{*}{ ST-02 } & \multirow{4}{*}{1350} & Grt $^{P}$ & 17 & $42.3(3)$ & $23.1(3)$ & $10.3(6)$ & 23 & - & $20.7(7)$ & $3.3(7)$ & 99.8 \\
\hline & & Mws $^{P}$ & 11 & - & - & $90.7(5)$ & 84 & 6 & $8.8(5)$ & $0.03(1)$ & 99.5 \\
\hline & & $\mathrm{Grt}^{\mathrm{C}}$ & 14 & $41.0(1)$ & $21.7(1)$ & $13.2(1)$ & 22 & - & $15.1(2)$ & $8.6(4)$ & 99.7 \\
\hline & & Mws ${ }^{C}$ & 16 & - & - & $93.4(9)$ & 93 & - & $5.8(9)$ & $0.02(0)$ & 99.3 \\
\hline \multirow{4}{*}{ ST-03 } & \multirow{4}{*}{1450} & Grt & 17 & $40.2(4)$ & $22.5(1)$ & $18.2(3)$ & 14 & 4 & $14.9(6)$ & $3.57(6)$ & 99.5 \\
\hline & & Mws & 14 & - & - & $89.9(2)$ & 90 & - & $9.41(6)$ & $0.04(1)$ & 99.3 \\
\hline & & Fsp & 5 & $1.9(1)$ & $47.9(1)$ & $37.3(2)$ & 30 & 7 & $12.0(1)$ & - & 99.1 \\
\hline & & $\mathrm{L}_{\text {carb-sil }}$ & 30 & $11.0(8)$ & $0.1(1)$ & $36(1)$ & 30 & 6 & $16(1)$ & $7(1)$ & 70.1 \\
\hline \multirow{4}{*}{ ST-04 } & \multirow{4}{*}{1550} & Grt & 20 & $40.4(4)$ & $21.4(4)$ & $20.3(2)$ & 16 & 4 & $14.7(2)$ & $2.5(2)$ & 99.4 \\
\hline & & Mws & 15 & - & - & $91.7(4)$ & 92 & - & $7.88(1)$ & $0.03(1)$ & 99.7 \\
\hline & & Fsp & 7 & $2.0(1)$ & $48.5(2)$ & $37.6(3)$ & 31 & 7 & $11.9(6)$ & - & 100.0 \\
\hline & & $\mathrm{L}_{\text {carb-sil }}$ & 31 & $12.8(9)$ & $2.0(4)$ & $43(1)$ & 34 & 10 & $11.5(9)$ & $5(1)$ & 74.2 \\
\hline \multirow{4}{*}{ ST-05 } & \multirow{4}{*}{1650} & Grt & 21 & $40.2(3)$ & $21.3(4)$ & 20.7 (3) & 16 & 5 & $14.4(2)$ & $3.0(2)$ & 99.6 \\
\hline & & Mws & 16 & - & - & $91.2(7)$ & 91 & - & $8.2(2)$ & $0.03(1)$ & 99.4 \\
\hline & & Fsp & 6 & $1.8(1)$ & $53.0(3)$ & 31.8 (3) & 27 & 5 & $13.9(9)$ & - & 100.4 \\
\hline & & $\mathrm{L}_{\text {carb-sil }}$ & 30 & $15.0(9)$ & $3.5(7)$ & $42.7(8)$ & 33 & 10 & $11.0(8)$ & $4.1(9)$ & 76.3 \\
\hline
\end{tabular}

Data were taken from the polished samples, coated with carbon. Grt, garnet, Mws, magnesiowustite, Fsp, ferrospinel, $\mathrm{L}_{\text {carb-sil, }}$ carbonate-silicate melt, $\mathrm{Fe}_{\text {tot }}$, total $\mathrm{Fe}^{2+}$ and $\mathrm{Fe}^{3+} ; \mathrm{N}_{\mathrm{A}}$, number of electron probe analyses. The values in parentheses are one sigma errors of the means reported as least units cited; ${ }^{\mathrm{P}}$, peripheral zone; ${ }^{C}$, central zone; $^{*}$, calculated according to Mössbauer spectroscopy data. 
Table $5 .{ }^{57} \mathrm{Fe}$ Mössbauer data for silicates, carbonates, oxides and melts.

\begin{tabular}{|c|c|c|c|c|c|c|c|}
\hline Run N & P, GPa & $\mathrm{T},{ }^{\circ} \mathrm{C}$ & Sample & Phase & $\begin{array}{c}\text { Iron } \\
\text { Valence }\end{array}$ & A, $\%$ & $\mathrm{Fe}^{3+} / \Sigma \mathrm{Fe}$ \\
\hline \multirow{6}{*}{ ST-01 } & \multirow{6}{*}{7.5} & \multirow{6}{*}{1250} & \multirow{3}{*}{$\begin{array}{l}\text { Central (reduced) } \\
\text { part }\end{array}$} & Coh & $\mathrm{Fe}^{0}$ & 18 & - \\
\hline & & & & Mws & $\mathrm{Fe}^{2+}$ & 76 & - \\
\hline & & & & Grt & $\mathrm{Fe}^{2+}(8)$ & 6 & - \\
\hline & & & \multirow{3}{*}{$\begin{array}{c}\text { Peripheral } \\
\text { (oxidized) part }\end{array}$} & \multirow{2}{*}{ Mws } & $\mathrm{Fe}^{2+}$ & 74 & \multirow{3}{*}{$\begin{array}{c}- \\
0.075 \\
-\end{array}$} \\
\hline & & & & & $\mathrm{Fe}^{3+}(4)$ & 6 & \\
\hline & & & & Grt & $\mathrm{Fe}^{2+}(8)$ & 20 & \\
\hline \multirow{11}{*}{ ST-04 } & \multirow{11}{*}{7.5} & \multirow{11}{*}{1550} & \multirow{5}{*}{$\begin{array}{c}\text { Quenched } \\
\text { carbonate-silicate } \\
\text { melt }\end{array}$} & Carb* & $\mathrm{Fe}^{2+}(6)$ & 62 & \multirow{5}{*}{$\begin{array}{l}0.18 \text { (in melt, } \\
\text { bulk) }\end{array}$} \\
\hline & & & & $\operatorname{Mot} *$ & $\mathrm{Fe}^{3+}(4)$ & 18 & \\
\hline & & & & $\mathrm{Mgt}$ & $\mathrm{Fe}^{2+}(8)$ & 5 & \\
\hline & & & & Opx * & $\mathrm{Fe}^{2+}(6)$ & 12 & \\
\hline & & & & Grt* & $\mathrm{Fe}^{2+}(8)$ & 4 & \\
\hline & & & \multirow{6}{*}{$\begin{array}{c}\text { Garnet aggregate } \\
\text { with interstitial melt }\end{array}$} & \multirow{2}{*}{ Grt } & $\mathrm{Fe}^{2+}(8)$ & 55 & \multirow{3}{*}{0.23} \\
\hline & & & & & $\mathrm{Fe}^{3+}(6)$ & 16 & \\
\hline & & & & Carb * & $\mathrm{Fe}^{2+}(6)$ & 12 & \\
\hline & & & & Mot* & $\mathrm{Fe}^{3+}(4)$ & 4 & \multirow{3}{*}{$\begin{array}{l}0.14 \text { (in melt, } \\
\text { bulk) }\end{array}$} \\
\hline & & & & $\mathrm{Mgt}$ & $\mathrm{Fe}^{2+}(8)$ & 2 & \\
\hline & & & & Opx * & $\mathrm{Fe}^{2+}(6)$ & 11 & \\
\hline \multirow{3}{*}{ CG-03 } & \multirow{3}{*}{6.3} & \multirow{3}{*}{1300} & \multirow{3}{*}{ Bulk sample } & & $\mathrm{Fe}^{2+}(8)$ & 49 & \multirow{3}{*}{0.17} \\
\hline & & & & Grt & $\mathrm{Fe}^{3+}(6)$ & 10 & \\
\hline & & & & Opx & $\mathrm{Fe}^{2+}(6)$ & 41 & \\
\hline \multirow{3}{*}{ CG-04 } & \multirow{3}{*}{6.3} & \multirow{3}{*}{1400} & \multirow{3}{*}{ Bulk sample } & & $\mathrm{Fe}^{2+}(8)$ & 52 & \multirow{3}{*}{$\begin{array}{c}0.24 \\
-\end{array}$} \\
\hline & & & & Grt & $\mathrm{Fe}^{3+}(6)$ & 16 & \\
\hline & & & & Opx & $\mathrm{Fe}^{2+}(6)$ & 26 & \\
\hline \multirow{3}{*}{ CG-05 } & \multirow{3}{*}{6.3} & \multirow{3}{*}{1500} & \multirow{3}{*}{ Bulk sample } & & $\mathrm{Fe}^{2+}(8)$ & 57 & \multirow{3}{*}{$\begin{array}{c}0.24 \\
-\end{array}$} \\
\hline & & & & Grt & $\mathrm{Fe}^{3+}(6)$ & 18 & \\
\hline & & & & Opx & $\mathrm{Fe}^{2+}(6)$ & 26 & \\
\hline
\end{tabular}

A: $\left(\operatorname{Area}\left(\mathrm{Fe}^{3+}\right) /\left(\mathrm{Area}\left(\mathrm{Fe}^{2+}\right)+\operatorname{Area}\left(\mathrm{Fe}^{3+}\right)\right) \times 100(\right.$ error $= \pm 3)$ or $\left(\mathrm{Area}\left(\mathrm{Fe}^{2+}\right) /\left(\mathrm{Area}\left(\mathrm{Fe}^{2+}\right)+\operatorname{Area}\left(\mathrm{Fe}^{3+}\right)\right) \times 100\right.$ $($ error $= \pm 3$ ). Number in parenthesis denotes coordination of iron. Grt, garnet, Coh, cohenite, Mws, magnesiowüstite, Mgt, magnetite, Opx, orthopyroxene, Carb, carbonate; *, quenched phase.

Cohenite in all samples demonstrates perfect stoichiometry with carbon content of $\sim 6.7 \mathrm{wt} \%$. The compositions of silicate and oxide phases crystallized in assemblage with iron carbide in the reduced parts of samples show higher $\mathrm{FeO}$ with respect to oxidized parts (Figure 3a). Thus, in central part of the samples, magnesiowüstite composition corresponds to $\mathrm{Fe}_{0.92} \mathrm{Mg}_{0.08} \mathrm{O}\left(1250{ }^{\circ} \mathrm{C}\right)$ and $\mathrm{Fe}_{0.9} \mathrm{Mg}_{0.1} \mathrm{O}\left(1350{ }^{\circ} \mathrm{C}\right)$, and garnets contain of $\sim 13 \mathrm{wt} \% \mathrm{FeO}$. In the peripheral parts, composition of magnesiowüstite is of $\mathrm{Fe}_{0.84-0.85} \mathrm{Mg}_{0.15-0.16} \mathrm{O}$ (Table 4, Figure 3), and $\mathrm{FeO}$ content in garnets is of 9-10 wt \%. Mössbauer spectroscopy results show that the most abundant phase in the samples under $7.5 \mathrm{GPa}$ and $1250-1350{ }^{\circ} \mathrm{C}$ is wüstite $\left(\mathrm{Fe}_{1-\mathrm{x}} \mathrm{O}\right)$, which incorporates up to $80 \%$ of all $\mathrm{Fe}$ in the system. Wüstite from the reduced parts of the samples is found to be free of trivalent iron. In the oxidized parts of the samples, $\mathrm{Fe}^{3+} / \Sigma \mathrm{Fe}$ values in wüstite amount up to $7.5 \%$ (Table 5). The carbide phase is identified only in the reduced part of the samples. Mössbauer parameters of silicates, revealed in the samples, corresponds to $\mathrm{Fe}^{2+}$ in garnet (Table 5 and Figure 4).
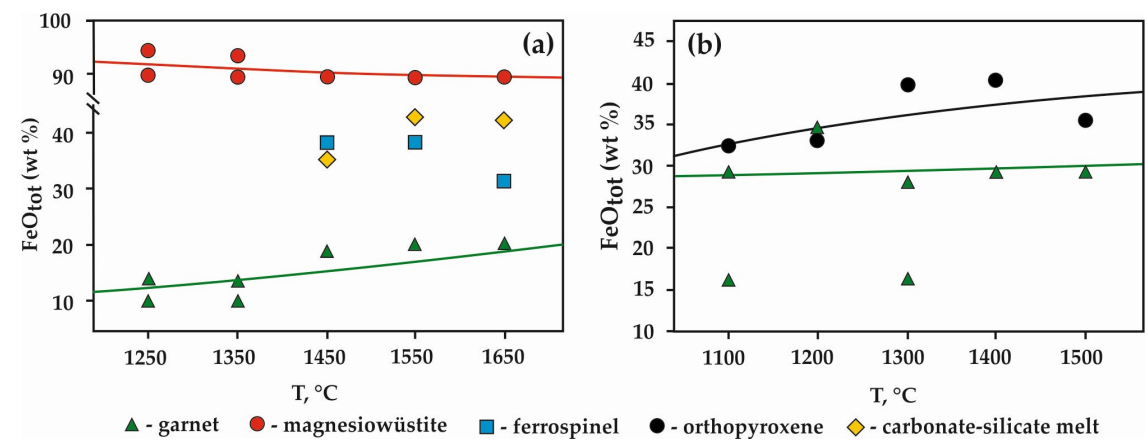

Figure 3. Temperature dependence of FeO content in silicate and oxide phases: (a) "sandwich"-type experiments, $\mathrm{P}=7.5 \mathrm{GPa}$; and $(\mathbf{b})$ "mixture"-type experiments, $\mathrm{P}=6.3 \mathrm{GPa}$. 

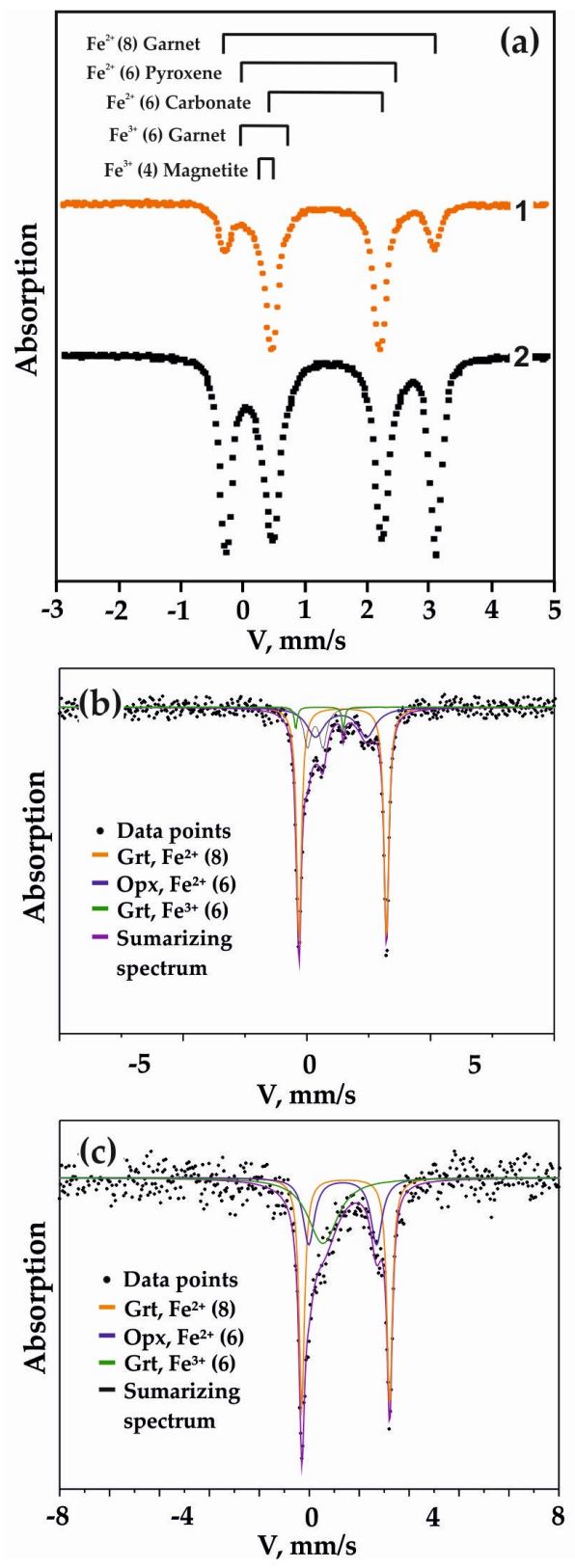

Figure 4. Room-temperature Mössbauer spectra: (a) spectra of different zones of samples after "sandwich"-type experiments at 7.5 GPa, $\mathrm{T}=1550{ }^{\circ} \mathrm{C}((1)$ quenched carbonate-silicate melt; and (2) polycrystalline garnet aggregate with quenched melt in interstices); and (b,c) spectra of garnets and orthopyroxenes after "mixture"-type experiments at $6.3 \mathrm{GPa}, \mathrm{T}=1400$ and $1500{ }^{\circ} \mathrm{C}$, respectively; Grt, garnet; Opx, orthopyroxene.

A principal scheme of the carbide-oxide-carbonate interaction at 7.5 GPa and in the temperature range of $1450-1650{ }^{\circ} \mathrm{C}$ is presented in Figure 1c. As a result of these experiments, cohenite is totally consumed, and reaction volume does not demonstrate subdivision to reduced and oxidized parts. However, in the central parts of the samples, large graphite crystals (up to $600 \mu \mathrm{m}$ ) with inclusions of cohenite and magnesiowüstite are formed (Figure 2b). These crystals are localized at the initial boundary between iron carbide and the carbonate-oxide ampoule. Growth of (100) and (111) faces of diamond seeds occurs, with the formation of the grown layers of $\sim 70$ and $120 \mu \mathrm{m}$, respectively. In the upper part of samples, pools of segregated carbonate-silicate melt are established (Figure 2d), in the central part-garnet + ferrospinel + graphite assemblage with interstitial melt (Figure 2e,f) was formed and crystallization of magnesiowüstite + garnet + graphite assemblage (Figure 2e) in the 
lower part occurred. The compositions of mineral phases and melt are constant within the samples. As temperature grows, garnet demonstrates a slight increase in FeO content from $18.2\left(1450{ }^{\circ} \mathrm{C}\right)$ to 20.7 wt \% $\left(1650{ }^{\circ} \mathrm{C}\right)$, and magnesiowüstite is characterized by a MgO content of $8-9.5$ wt \% (Table 4 and Figure 3a). Ferrospinel has composition of $\sim\left(\mathrm{Fe}_{0.5} \mathrm{Mg}_{0.5}\right)\left(\mathrm{Al}_{1.58} \mathrm{Fe}_{0.42}\right) \mathrm{O}$. Quenched carbonate-silicate melt consists of orthopyroxene, ferromagnesite, garnet and magnetite microdendrites as well as graphite microspheres of 3-30 $\mu \mathrm{m}$ in size (Figure $2 \mathrm{~d}-\mathrm{e}$ ). Bulk analysis of the quenched aggregates shows that $\mathrm{SiO}_{2}$ and $\mathrm{Al}_{2} \mathrm{O}_{3}$ content in the melt increases, and $\mathrm{MgO}$ and $\mathrm{CaO}$ concentrations decrease with temperature (Table 4). $\mathrm{CO}_{2}$ content in this melt is of 26-30 wt \%. The Mössbauer spectroscopy data demonstrate that quenched carbonate-silicate melt, garnet and ferrospinel contain trivalent iron (Table 5 and Figure 4a). It is established that bulk aggregate of quenched carbonate-silicate melt is characterized by values of $0.18-0.19$, and all $\mathrm{Fe}^{3+}$ therein presents in form of quenched magnetite; garnet, crystallized in this melt, has a value of $\sim 0.20-0.22$.

\subsection{Experimental Results in the Carbide-Oxide-Carbonate System at the Pressure of 6.3 GPa ("Mixture"-Type of Experiments without $\mathrm{fO}_{2}$-Gradient)}

The experimental results, compositions of final phases, and structures of experimental samples are given in Tables 3 and 6 and in Figures 3 and 5. An assemblage of garnet, orthopyroxene, magnetite, graphite, \pm ferropericlase as well as small amounts of corundum and coesite are obtained at the lowest temperatures (1100-1200 ${ }^{\circ} \mathrm{C}$ ) (Figures 5 and 6). After experiments, there are no carbide and carbonate in ampoules. Magnetite occurs primarily in the ampoule parts where large carbide crystals were initially placed. Crystals of newly formed silicates and oxides are characterized by a size of 5-20 $\mu \mathrm{m}$. Graphite forms elongated crystals and their aggregates are up to $70 \mu \mathrm{m}$ in size. According to the difference in iron concentrations, garnet can be subdivided into two groups, with FeO content of $\sim 17$ wt \% and $\sim 30$ wt \%, respectively. Higher-ferrous garnets occur primarily in the ampoule parts where large carbide crystals were initially placed. Orthopyroxene formed in the experiments has a homogeneous composition and is characterized by a FeO content of $\sim 33 \mathrm{wt} \%$ and a very low $\mathrm{CaO}$ concentration of $\sim 0.7 \mathrm{wt} \%$.

Table 6. Average compositions of silicates and oxides in the carbide-oxide-carbonate system ("mixture-type" experiments) at $6.3 \mathrm{GPa}$, according to microprobe analysis.

\begin{tabular}{|c|c|c|c|c|c|c|c|c|c|c|c|}
\hline \multirow{2}{*}{ Run N } & \multirow{2}{*}{$\mathrm{T},{ }^{\circ} \mathrm{C}$} & \multirow{2}{*}{ Phase } & \multirow{2}{*}{$\mathbf{N}_{\mathrm{A}}$} & \multicolumn{8}{|c|}{ Mass Concentrations, wt \% } \\
\hline & & & & $\mathrm{SiO}_{2}$ & $\mathrm{Al}_{2} \mathrm{O}_{3}$ & $\mathrm{FeO}$ & $\mathrm{FeO} *$ & $\mathrm{Fe}_{2} \mathrm{O}_{3}$ * & $\mathrm{MgO}$ & $\mathrm{CaO}$ & Total \\
\hline \multirow{5}{*}{ CG-01 } & \multirow{5}{*}{1100} & Grt & 14 & $40(2)$ & $25(3)$ & $17(3)$ & $17(3)$ & - & $14(3)$ & $4(2)$ & 99.7 \\
\hline & & & 9 & $38.5(5)$ & $21.3(8)$ & $30(3)$ & $30(3)$ & - & $6(1)$ & $4(2)$ & 100.1 \\
\hline & & Opx & 12 & $50.7(8)$ & - & $33(1)$ & $33(1)$ & - & $14.4(8)$ & $0.7(3)$ & 99.4 \\
\hline & & Mgt & 5 & - & - & $91.1(2)$ & 20 & 71 & $7.0(2)$ & - & 98.1 \\
\hline & & $\mathrm{Fpc}$ & 6 & - & - & $30.7(9)$ & 31 & - & $68.4(8)$ & - & 99.1 \\
\hline \multirow{3}{*}{ CG-02 } & \multirow{3}{*}{1200} & Grt & 10 & $38.3(1)$ & $18.8(8)$ & $33.9(1)$ & 31 & 3 & $6.1(9)$ & $2.5(9)$ & 99.6 \\
\hline & & Opx & 10 & $50.9(6)$ & $0.4(3)$ & $33(1)$ & - & - & $14.5(8)$ & $0.6(2)$ & 99.7 \\
\hline & & Mgt & 6 & - & - & $91.5(2)$ & 20 & 71 & $7.5(1)$ & - & 98.0 \\
\hline \multirow{4}{*}{ CG-03 } & \multirow{4}{*}{1300} & $\mathrm{Grt}^{\mathrm{C}}$ & 12 & $37.5(1)$ & $22.5(5)$ & $28.6(8)$ & 23 & 5 & $8.9(6)$ & $2.1(1)$ & 99.5 \\
\hline & & $\mathrm{Grt}^{\mathrm{R}}$ & 16 & $39.0(5)$ & $25.8(4)$ & $16(2)$ & $15(2)$ & $\sim 1$ & $14(1)$ & $4.2(7)$ & 99.5 \\
\hline & & Opx & 1 & $49.4(3)$ & - & $40.4(5)$ & 40 & - & $10.2(5)$ & - & 99.9 \\
\hline & & Mgt & 6 & - & - & $90.8(2)$ & 20 & 71 & $7.6(2)$ & - & 98.4 \\
\hline \multirow{2}{*}{ CG-04 } & \multirow{2}{*}{1400} & Grt & 15 & $38.6(4)$ & $21.1(6)$ & $28.7(5)$ & 22 & 7 & $9.4(2)$ & $1.7(4)$ & 99.5 \\
\hline & & Opx & 7 & $49.2(3)$ & - & $41.0(7)$ & 41 & - & $9.2(6)$ & - & 99.5 \\
\hline \multirow{2}{*}{ CG-05 } & \multirow{2}{*}{1500} & Grt & 15 & $39.3(4)$ & $21.1(3)$ & $28(1)$ & 22 & 7 & $10.0(6)$ & $1.7(4)$ & 99.9 \\
\hline & & Opx & 12 & $50(1)$ & $0.4(3)$ & $35.4(7)$ & - & - & $5.6(5)$ & 7.5 (10) & 99.5 \\
\hline
\end{tabular}

Data were taken from the polished samples, coated with carbon. Grt, garnet; Opx, orthopyroxene; Mgt, magnetite; Fpc, ferropericlase; $C$, center; $R$, rim; $N_{A}$, number of electron probe analyses used to obtain the average compositions. The values in parentheses are one sigma errors of the means based on replicate electron microprobe analyses reported as least units cited. ${ }^{*}$, calculated according to Mössbauer spectroscopy data. 

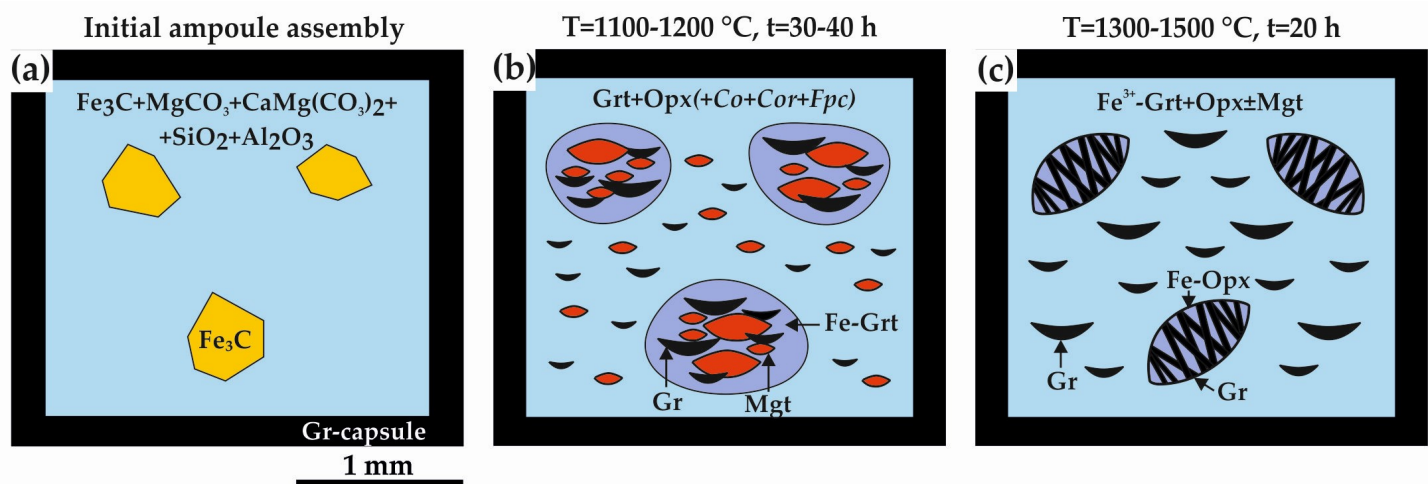

Figure 5. Schemes of carbide-oxide-carbonate interaction in the "mixture-type" experiments $\left(\mathrm{Fe}_{3} \mathrm{C}-\mathrm{Al}_{2} \mathrm{O}_{3}-\mathrm{SiO}_{2}-(\mathrm{Mg}, \mathrm{Ca}) \mathrm{CO}_{3}\right.$ system, $\left.\mathrm{P}=6.3 \mathrm{GPa}\right)$ : (a) initial ampoule assembly (before experiments); (b) samples after experiments at $1100-1200{ }^{\circ} \mathrm{C}, \mathrm{t}=30-40 \mathrm{~h}$; and (c) samples after experiments at 1300-1500 ${ }^{\circ} \mathrm{C}, \mathrm{t}=20 \mathrm{~h}$. Grt, garnet; Coh, cohenite; Mgt, magnetite; Opx, orthopyroxene; Fe-Opx, Fe-rich orthopyroxene; $\mathrm{Gr}$, graphite; $\mathrm{Fe}^{3+}$-Grt, garnet, enriched with trivalent iron, Fpc, ferropericlase.
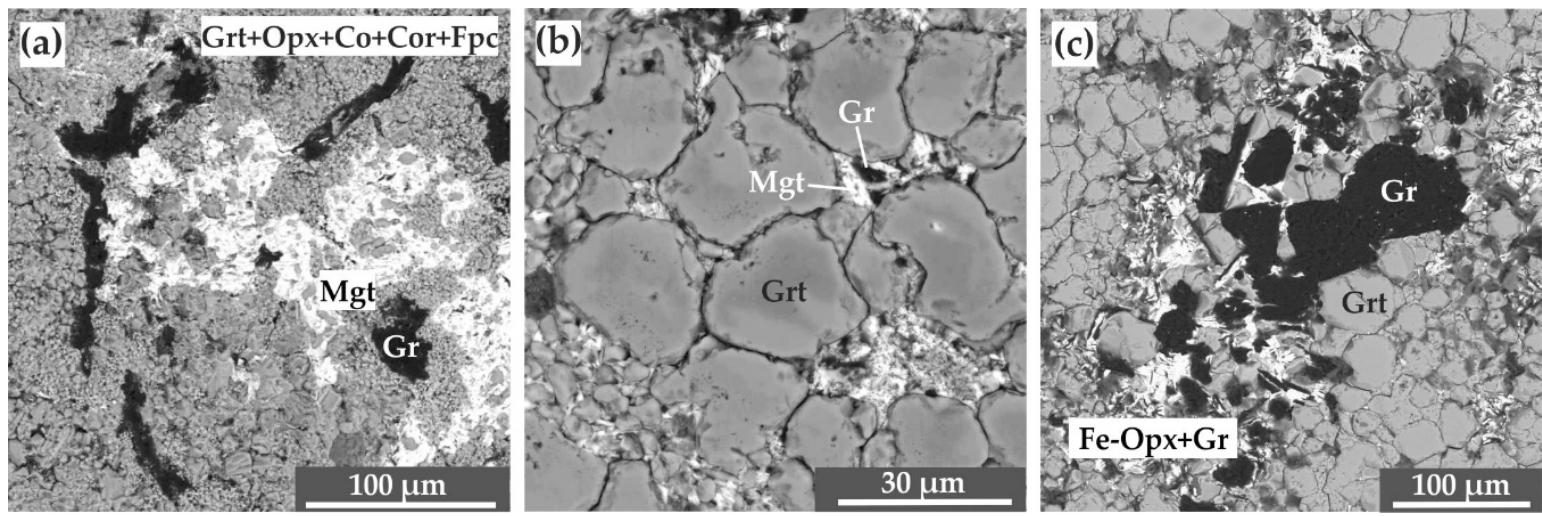

Figure 6. SEM-micrographs (BSE-regime) of polished fragments of the samples ("mixture"-type experiments, $\mathrm{Fe}_{3} \mathrm{C}-\mathrm{Al}_{2} \mathrm{O}_{3}-\mathrm{SiO}_{2}-(\mathrm{Mg}, \mathrm{Ca}) \mathrm{CO}_{3}$ system, $\left.\mathrm{P}=6.3 \mathrm{GPa}\right)$ : (a) polycrystalline aggregate of newly-formed garnet, orthopyroxene, magnetite and graphite and recrystallized cohenite and corundum $\left(1100{ }^{\circ} \mathrm{C}\right)$; (b) zoned garnet crystals with magnetite + graphite in the interstitials $\left(1300^{\circ} \mathrm{C}\right)$; and $(\mathbf{c})$ graphite + Fe-rich orthopyroxene assemblage in polycrystalline garnet aggregate $\left(1500^{\circ} \mathrm{C}\right)$. Grt, garnet; Opx, orthopyroxene; Cor, corundum; Co, coesite; Mgt, magnetite; Opx, orthopyroxene; Gr, graphite; Fe-Opx, Fe-rich orthopyroxene; Fpc, ferropericlase.

At temperature of $1300{ }^{\circ} \mathrm{C}$ and pressure of $6.3 \mathrm{GPa}$, the carbide-oxide-carbonate interaction led to the formation of an assemblage of garnet, orthopyroxene, graphite, and magnetite (Figure 5b). The prevailing phase in the reaction volume of ampoules is garnet. Most garnet crystals have a zonal structure (Figure 6b); their central parts have high FeO content of about 28 wt \%; their rims are characterized by higher concentrations of $\mathrm{MgO}$ as well as lower $\mathrm{CaO}$ concentrations (Table 6). The size of garnet crystals is $5-40 \mu \mathrm{m}$. Some garnet crystals have inclusions of a quenched Fe-C melt and graphite. Fine-crystalline orthopyroxene, magnetite, and graphite present in interstices of a polycrystalline garnet aggregate (Figure 6b). The orthopyroxene composition is heterogeneous. The FeO concentration in orthopyroxene varies from 11.5 to $40.4 \mathrm{wt} \%$.

At higher temperatures $\left(1400\right.$ and $\left.1500^{\circ} \mathrm{C}\right)$, the carbide-oxide-carbonate interaction leads to the formation of the garnet + orthopyroxene+graphite assemblage (Figure $4 b, c$ ). Garnet is characterized by a homogeneous composition with high $\mathrm{FeO}$ content of about $28 \mathrm{wt} \%$ and a crystal size of $\sim 30-70 \mu \mathrm{m}$ (Figure 6c). It should be separately noted that garnet has $\mathrm{Fe}^{3+} / \Sigma \mathrm{Fe}$ values of 0.24 (Table 5). Garnet has inclusions of a quenched $\mathrm{Fe}-\mathrm{C}$ melt and graphite. Interstices of the garnet matrix are comprised by a fine-crystalline aggregate of orthopyroxene and graphite. The parts of samples, 
where large carbide crystals were initially placed, contain highly-ferrous orthopyroxene and large graphite crystals (Figure 5C). The composition of orthopyroxene crystallized at $1400{ }^{\circ} \mathrm{C}$ and $1500{ }^{\circ} \mathrm{C}$ is $\mathrm{Fe}_{1.41} \mathrm{Mg}_{0.56} \mathrm{Si}_{2.02} \mathrm{O}_{6}$ and $\mathrm{Fe}_{1.22} \mathrm{Mg}_{0.34} \mathrm{Ca}_{0.33} \mathrm{Si}_{2.08} \mathrm{O}_{6}$, respectively (Table 6).

The experimental data and Mössbauer spectroscopy results revealed the main patterns of a $\mathrm{Fe}^{3+}$ distribution between the final phases. In the experiments at $6.3 \mathrm{GPa}$ and $1100{ }^{\circ} \mathrm{C}$, all ferric iron is included in magnetite. In a range of $1200-1300{ }^{\circ} \mathrm{C}, \mathrm{Fe}^{3+}$-garnet coexists with magnetite; at 1400 and $1500{ }^{\circ} \mathrm{C}$, garnet is the only sink for ferric iron (Table 5 and Figure $4 \mathrm{~b}, \mathrm{c}$ ). It should be noted that inclusions of a Fe-C melt are found in garnets enriched with ferric iron, which indicates the presence (and participation) of a predominantly metal melt in the processes of the crystallization of $\mathrm{Fe}^{3+}$-bearing garnet.

\section{Discussion}

\subsection{General Reconstruction of Carbide-Oxide-Carbonate Interaction Processes}

\subsubsection{Carbide-Oxide-Carbonate System ("Sandwich"-Type Experiments, P = 7.5 GPa)}

Results of the present study and previous experimental research $[18,48]$ demonstrate that the main processes occurring in the system are redox interactions involving iron carbide and decarbonation reactions. In the reduced part of the reaction volume, redox interaction between carbonates and iron carbide are realized to produce an association of magnesiowustite + graphite + Ca-rich carbonate (Reaction (3)) [18]:

$$
2 \mathrm{Fe}_{3} \mathrm{C}+4(\mathrm{Mg}, \mathrm{Ca}) \mathrm{CO}_{3} \rightarrow 9(\mathrm{Fe}, \mathrm{Mg}, \mathrm{Ca}) \mathrm{O}+(\mathrm{Ca}, \mathrm{Mg}, \mathrm{Fe}) \mathrm{CO}_{3}+5 \mathrm{C}^{0}
$$

Partial oxidation of cohenite results in the formation of $\mathrm{Fe}$,Ca-bearing pyrope in the reaction zone by the parallel realization of Reactions (4) and (5):

$$
\begin{gathered}
3(\mathrm{Fe}, \mathrm{Mg}, \mathrm{Ca}) \mathrm{O}+3 \mathrm{SiO}_{2}+\mathrm{Al}_{2} \mathrm{O}_{3} \rightarrow(\mathrm{Fe}, \mathrm{Mg}, \mathrm{Ca})_{3} \mathrm{Al}_{2} \mathrm{Si}_{3} \mathrm{O}_{12} \\
3(\mathrm{Mg}, \mathrm{Ca}, \mathrm{Fe}) \mathrm{CO}_{3}+3 \mathrm{SiO}_{2}+\mathrm{Al}_{2} \mathrm{O}_{3} \rightarrow(\mathrm{Fe}, \mathrm{Mg}, \mathrm{Ca})_{3} \mathrm{Al}_{2} \mathrm{Si}_{3} \mathrm{O}_{12}+3 \mathrm{CO}_{2}
\end{gathered}
$$

In the course of decarbonation (Reaction (5)), minor amounts of $\mathrm{CO}_{2}$ fluid are released and then consumed via redox interaction with iron carbide that results in the formation of graphite near the boundary of the central reduced zone with the peripheral oxidized part of the sample (Reaction (2)). In the oxidized part of the reaction volume, crystallization of garnet proceeds through decarbonation (Reaction (5)) with $\mathrm{CO}_{2}$ fluid generation (Figure 7). However, part of garnet crystallizes in experiments as a result of $(\mathrm{Fe}, \mathrm{Mg}) \mathrm{O}-\mathrm{SiO}_{2}-\mathrm{Al}_{2} \mathrm{O}_{3}$ interaction without the participation of carbonate. Mössbauer data on the formation of $\mathrm{Fe}^{3+}$-bearing magnesiowüstite evidence that crystallization of graphite in the oxidized part of the reaction volume in assemblage with garnet and magnesiowüstite (Figure 1b) can occur via redox interaction of magnesiowüstite with $\mathrm{CO}_{2}$ fluid (Reaction (6)). During reduction of $\mathrm{CO}_{2}$ to $\mathrm{C}^{0}$, ferrous iron from magnesiow üstite is partially oxidized to $\mathrm{Fe}^{3+}$ :

$$
(\mathrm{Fe}, \mathrm{Mg}) \mathrm{O}+\mathrm{CO}_{2} \rightarrow 3\left(\mathrm{Fe}^{2+}, \mathrm{Mg}, \mathrm{Fe}^{3+}\right)_{1-\mathrm{x}} \mathrm{O}+2 \mathrm{C}^{0}
$$

The phase compositions of reduced and oxidized parts of the samples show that, at the temperature range of $1250-1350{ }^{\circ} \mathrm{C}$, redox gradient is preserved in the reaction ampoule. In the center of the samples, where only cohenite is present, and in the reaction zone consisted of cohenite, magnesiowüstite, garnet and graphite, the $f \mathrm{O}_{2}$ values are close to those of the iron-wüstite buffer. In the peripheral oxidized part of the ampoule, where $\mathrm{Fe}^{3+}$-bearing magnesiowüstite + garnet + graphite assemblage are formed, $f \mathrm{O}_{2}$ values are close to $\mathrm{CCO}$ buffer (moreover, these are provided by graphite capsules). 


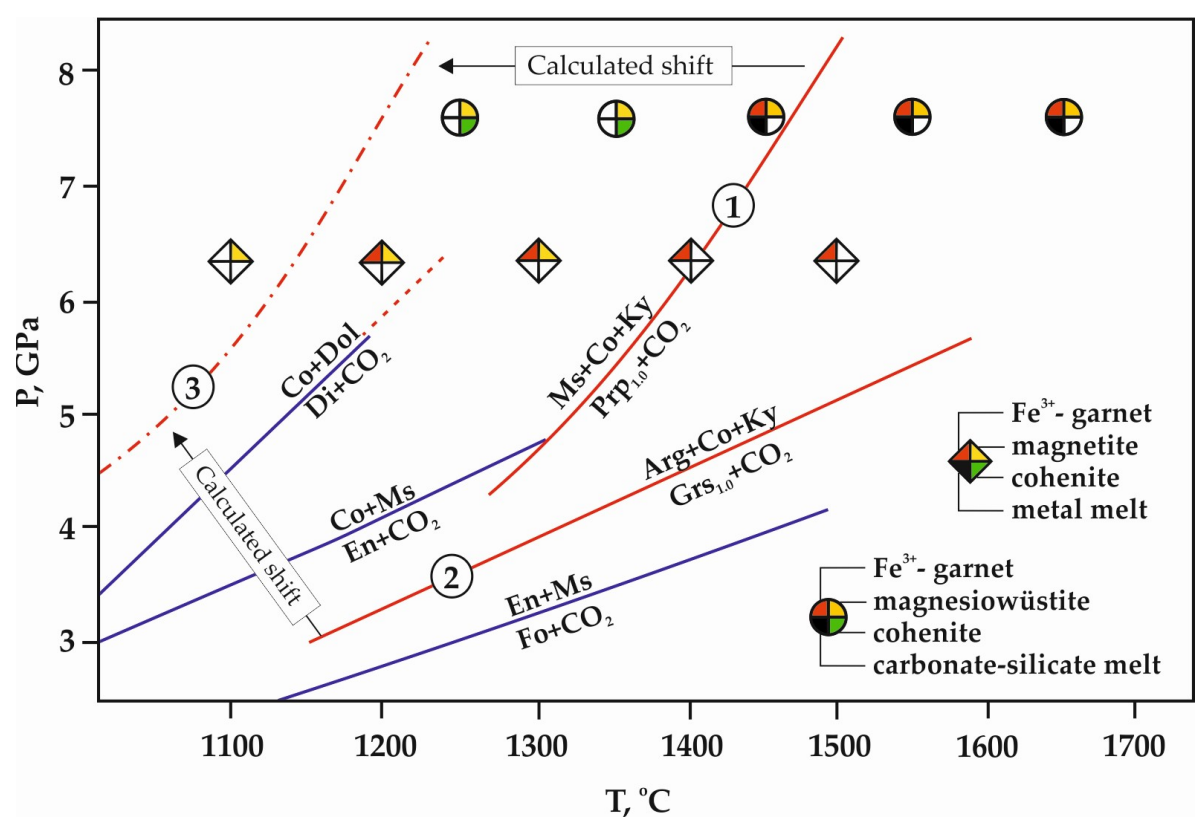

Figure 7. P,T-diagram with experimental results of the carbide-oxide-carbonate interaction "sandwich"-type (circles) and "mixture"-type (rhombs) experiments, with experimentally determined or calculated decarbonation curves [52-54]. Color of symbols denotes variations in Fe-bearing phases. Calculated shift of Reactions (1) and (2), which results in Reaction (3), are shown according to EC1 garnet compositions [54]. Co, coesite; Dol, dolomite; Di, diopside; Ms, magnesite; En, enstatite; Ky, kyanite; Prp, pyrope; Grs, grossular.

Under higher temperatures $\left(1450-1650^{\circ} \mathrm{C}\right)$, final samples do not demonstrate subdivision into reduced and oxidized parts; however, redox gradient at early stages of experiments can be considered as a powerful driving force of the phase formation processes. During carbide-oxide-carbonate interaction, a series of processes are realized, involving redox interaction between carbonates and iron carbide, decarbonation reactions and partial melting. Most probably, at the first stages of interaction, phase formation occurred through Reaction (3), with $\mathrm{Fe}, \mathrm{Mg}, \mathrm{Ca}$-carbonates, magnesiowüstite and graphite crystallization, as well as decarbonation (Reaction (5)) which led to the formation of Fe-enriched garnet and $\mathrm{CO}_{2}$ fluid. Next, the generation of carbonate-silicate melt occurs. As a result, the redox interaction of carbonate-bearing melt and $\mathrm{CO}_{2}$ fluid with cohenite, crystallization of graphite takes place. This process is accompanied by the melt enrichment in $\mathrm{FeO}$ :

$$
\mathrm{Fe}_{3} \mathrm{C}+\mathrm{L}_{\text {carb-sil }} \rightarrow \mathrm{L}_{\text {carb-sil }}+\mathrm{FeO}_{\text {in melt }}+\mathrm{C}^{0}
$$

When iron carbide is totally consumed, redox Reaction (7) is discontinued, and, in the central part of the reaction volume, large graphite crystals with inclusions of cohenite are formed. After finishing of this redox interaction, the smoothing of $f \mathrm{O}_{2}$ gradients in the samples occurs, with overall $f \mathrm{O}_{2}$ values close to $\mathrm{CCO}$ buffer. The interaction of iron oxides dissolved in the carbonate-silicate melt with $\mathrm{CO}_{2}$ fluid, released via decarbonation, results in a partial oxidation of $\mathrm{Fe}^{2+}$ to $\mathrm{Fe}^{3+}$ and the melt saturation with elemental carbon and crystallization of graphite:

$$
\mathrm{FeO}_{\text {in melt }}+\mathrm{CO}_{2} \rightarrow \mathrm{Fe}_{3} \mathrm{O}_{4} \text { in melt }+\mathrm{C}^{0}
$$

\subsubsection{Carbide-Oxide-Carbonate System ("Mixture"-Type experiments)}

Based on a detailed study of experimental samples and data of previous studies [55,56], we conclude that the main processes of carbide-oxide-carbonate interaction at the lowest temperatures $\left(1100-1200^{\circ} \mathrm{C}\right.$ ) include: (i) decarbonation resulting in the release of $\mathrm{CO}_{2}$-dominated fluid and the 
formation of garnet and orthopyroxene (Reactions (1) and (9)); and (ii) the subsequent redox interaction between iron carbide and the resulting fluid (Reaction (10)):

$$
\begin{gathered}
2(\mathrm{Mg}, \mathrm{Ca}) \mathrm{CO}_{3}+2 \mathrm{SiO}_{2} \rightarrow(\mathrm{Mg}, \mathrm{Ca})_{2} \mathrm{Si}_{2} \mathrm{O}_{6}+2 \mathrm{CO}_{2} \\
3 \mathrm{Fe}_{3} \mathrm{C}+5 \mathrm{CO}_{2} \rightarrow 6 \mathrm{FeO}_{\text {in silicates, oxides }}+\mathrm{FeFe}_{2} \mathrm{O}_{4}+8 \mathrm{C}^{0}
\end{gathered}
$$

Decarbonation plays a key role in the phase formation processes in the carbide-oxide-carbonate system. It should be noted that the temperatures of partial and complete decarbonation of the cohenite-involving system are in good agreement with ones in the $(\mathrm{Mg}, \mathrm{Ca}) \mathrm{CO}_{3}-\mathrm{SiO}_{2}-\mathrm{Al}_{2} \mathrm{O}_{3}-\mathrm{FeO}$ system at similar pressures [51]. In the experiments, decarbonation reactions occurred at $1100{ }^{\circ} \mathrm{C}$, whereas according to Knoche co-authors [53], decarbonation with formation of pure pyrope at $6.3 \mathrm{GPa}$ can proceed at temperatures higher than $1400^{\circ} \mathrm{C}$. Using the calculation results [54] and experimental data [53] for reconstructing the decarbonation curve of a produced solid solution of $\mathrm{Alm}_{70} \operatorname{Prp}_{20} \mathrm{Grs}_{10}$ garnet, typical of carbonated eclogites EC1, we found that at $6.3 \mathrm{GPa}$ decarbonation started at about $1100{ }^{\circ} \mathrm{C}$ (Figure 7).

We found that the redox interaction (Reaction (10)) leads to: (i) oxidation of cohenite to magnetite (separate phase) and $\mathrm{FeO}$ (in silicates and oxides), which is accompanied by carbon extraction and graphite crystallization; and (ii) reduction of $\mathrm{CO}_{2}$ fluid by cohenite to $\mathrm{C}^{0}$ (graphite). Therefore, if Reactions (2), (9), and (10) proceed simultaneously, an assemblage of Fe-rich silicates, graphite, and magnetite forms. According to Mössbauer spectroscopy, all ferric iron formed during cohenite oxidation is included in magnetite. It should be noted that decarbonation of the system at these temperatures is complete, but initial oxides partially remain in the reaction volume. Given the initial proportions of $\mathrm{SiO}_{2}, \mathrm{Al}_{2} \mathrm{O}_{3}, \mathrm{MgCO}_{3}$, and $\mathrm{CaMg}\left(\mathrm{CO}_{3}\right)_{2}$, the absence of carbonates among final phases indicates that there was a redox interaction between magnesite and iron carbide, which is confirmed by the presence of ferropericlase in the reaction volume:

$$
2 / 3 \mathrm{Fe}_{3} \mathrm{C}+\mathrm{MgCO}_{3} \rightarrow 3(\mathrm{Mg}, \mathrm{Fe}) \mathrm{O}+5 / 3 \mathrm{C}^{0}
$$

The performed experiments indicate that complete decarbonation of the system (Reactions (1) and (9)), redox interaction between $\mathrm{CO}_{2}$-fluid and iron carbide (Reaction (12)), and partial melting occur in a temperature range of $1300-1500{ }^{\circ} \mathrm{C}$ :

$$
3 \mathrm{Fe}_{3} \mathrm{C}+3 \mathrm{CO}_{2} \rightarrow 6 \mathrm{FeO}_{\text {in silicates }}+3 \mathrm{Fe}-\mathrm{C}_{\text {melt }}+5 \mathrm{C}^{0}
$$

The redox interaction (Reaction (12)) leads to the formation of elemental carbon (graphite \pm diamond growth), a Fe-C melt, and also $\mathrm{FeO}$ that does not form an independent phase, but is included in silicates (garnet and orthopyroxene). In this case, new portions of a $\mathrm{CO}_{2}$-fluid formed at subsequent stages of experiments are involved the redox interaction with a $\mathrm{Fe}-\mathrm{C}$ melt:

$$
3 \mathrm{Fe}-\mathrm{C}_{\text {melt }}+3 \mathrm{CO}_{2} \rightarrow 6 \mathrm{FeO}_{\text {in silicates }}+4 \mathrm{C}^{0}
$$

Reactions (12) and (13) lead to complete oxidation of cohenite and a Fe-C melt, which results in the formation of an assemblage of Fe-rich garnet, Fe-rich orthopyroxene, and graphite as well as in diamond growth on seed crystals $\left(1500^{\circ} \mathrm{C}\right)$. All ferric iron formed in these reactions is concentrated in garnet.

A set of phases produced in the experiments at $1100-1300{ }^{\circ} \mathrm{C}\left(\mathrm{Fe}^{2+}\right.$-bearing silicates, magnetite, and graphite) designates $f \mathrm{O}_{2}$ values close to the $\mathrm{C}-\mathrm{CO}$ and wüstite-magnetite (WM) buffer equilibria. In this temperature range, $f \mathrm{O}_{2}$ values characteristic of the WM buffer are within the stability field of elemental carbon. $\mathrm{A} \mathrm{Fe}^{2+}, \mathrm{Fe}^{3+}$-garnet + graphite assemblage produced at higher temperatures does not contain phase-markers of redox conditions, but, given $\mathrm{Fe}^{2+}$ and $\mathrm{Fe}^{3+}$ proportions in garnet, its 
oxygen fugacity values may be estimated as close to the WM buffer and definitely not higher than $\mathrm{CCO}$ one (this upper $f \mathrm{O}_{2}$ limit is set by outer graphite capsules).

\subsection{Reconstruction of Elemental Carbon Formation Processes}

One of the key issues addressed in modern studies on diamond formation in nature is the problem of a carbon source in the processes of mantle diamond formation. Potential carbon sources include $\mathrm{C}-\mathrm{O}-\mathrm{H}-\mathrm{N}$ fluid species, carbonates (carbonate-bearing melts), carbides, and metal-carbon melts [2,12,27,32,57-59]. Most of these hypotheses are confirmed by experiments [60-64]. It should be noted that experimental studies of the role of iron carbides in natural diamond formation are now very rare. In this section, we propose potential mechanisms for the formation of graphite and diamond growth in a course of carbide-oxide-carbonate interaction.

Graphite Formation and Diamond Growth from Carbon of Carbide and Carbonate

Reconstruction of the processes of phase formation in the carbide-oxide-carbonate system revealed the characteristic features of graphite formation and diamond growth in carbon-producing processes in relatively low- $\left(1100-1200{ }^{\circ} \mathrm{C}\right)$ and high-temperature $\left(1300-1500{ }^{\circ} \mathrm{C}\right)$ experiments. Crystallization of metastable graphite occurs in the entire temperature range, and diamond growth on seed crystals is observed at a temperature of $1500{ }^{\circ} \mathrm{C}$. It should be noted that a carbon source in this system is not only carbide but also carbonate. At relatively low temperatures, graphite forms due to simultaneous realization of the decarbonation reactions (Reactions (1) and (9)) and the redox interaction between a $\mathrm{CO}_{2}$-dominated fluid and iron carbide (Reaction (2)). This redox interaction may be considered as a basis for reconstruction of the mechanism of graphite formation in a temperature range of $1100-1200{ }^{\circ} \mathrm{C}$. The formation of graphite from carbon of carbide occurs during oxidation of cohenite by the fluid to $\mathrm{FeO}$ and $\mathrm{Fe}_{2} \mathrm{O}_{3}$ (in form of magnetite, silicates, and oxides) and is due to accompanying extraction of carbon from $\mathrm{Fe}_{3} \mathrm{C}$. Oxidation of the cohenite is accompanied by a corresponding reduction of $\mathrm{CO}_{2}$ to $\mathrm{C}^{0}$, leading to crystallization of metastable graphite, the source of which is carbonate. We suppose that the most likely environment for graphite formation by this mechanism is the $\mathrm{CO}_{2}$-dominated fluid.

At higher temperatures, the formation of metastable graphite was found to occur both via the described mechanisms and via the redox interaction between the $\mathrm{CO}_{2}$-dominated fluid and a predominantly metal melt $(\mathrm{Fe}-\mathrm{C})$, according to Reaction (13). Under these conditions, the formation of metastable graphite $\left(1300-1500{ }^{\circ} \mathrm{C}\right)$ and diamond growth on seed crystals $\left(1500{ }^{\circ} \mathrm{C}\right)$ occur due to complete oxidation of a $\mathrm{Fe}-\mathrm{C}$ melt by the fluid, which is accompanied by the formation of $\mathrm{Fe}^{2+}, \mathrm{Fe}^{3+}$-bearing silicates and, correspondingly, due to reduction of the $\mathrm{CO}_{2}$-dominated fluid to $\mathrm{C}^{0}$. We suppose that media for graphite crystallization and diamond growth via this mechanism are both $\mathrm{CO}_{2}$-dominated fluid and $\mathrm{Fe}-\mathrm{C}$ melt, and both carbide and carbonate acted as carbon sources.

One of the potential reasons for crystallization of graphite in the P,T-field of diamond stability is the inhibitory effect of impurities present in the melt, e.g., oxygen and nitrogen adsorbed on the starting reagents. Investigation of diamond crystallization in metal-carbon systems in the presence of impurities demonstrated that $\sim 0.48 \mathrm{wt} \% \mathrm{H}_{2} \mathrm{O}$ or $\sim 0.1 \mathrm{wt} \%$ nitrogen in a Fe-Ni-C melt was sufficient for the formation of metastable graphite in the thermodynamic stability field of diamond $[44,65]$.

\subsection{Scenarios of the Cohenite-Fluid Interaction in the Presence of Silicates in Natural Deep Mantle Environments}

The experimental results as well as data of thermodynamic calculations indicate that oxygen fugacity values in the lithospheric mantle at depths of about $250 \mathrm{~km}$ correspond to those of the iron-wüstite buffer [3,5-8]. The content of metallic iron spread to a metal-saturated mantle at depths of $\sim 250 \mathrm{~km}$ is estimated to be $\sim 0.1-0.2 \mathrm{wt} \%$ (1400 ppm) [6,7]. Previous studies [4,9,10] demonstrated that at bulk carbon concentrations corresponding to undepleted mantle conditions (300-800 ppm C), iron is most likely included in carbides $\left(\mathrm{Fe}_{3} \mathrm{C}\right.$ and $\left.\mathrm{Fe}_{7} \mathrm{C}_{3}\right)$. 
An interaction between cohenite and $\mathrm{CO}_{2}$-fluid or carbonate-silicate melts very likely occurs under lithospheric mantle conditions where it may be considered as one of the potential $\mathrm{C}^{0}$-producing processes [38] as well as a potential mechanism of $\mathrm{Fe}^{2+, 3+}$-bearing garnet formation. In addition, the processes of graphite or diamond formation by carbon extraction from carbide are accompanied by the generation of a predominantly metal melt at temperatures substantially lower than cohenite melting temperatures. During subduction of crustal material to great depths, highly reduced phases may interact with an oxidized slab that is a source of carbonates and $\mathrm{CO}_{2}$ fluid. Under subduction conditions, the most typical reactions are decarbonation processes occurring during the interaction between carbonate material and mantle oxides or silicates. However, subducted $\mathrm{Mg}-\mathrm{Ca}$ carbonates can be stable up to lower mantle depths $[32,59,66]$. As shown in studies $[45,54,67]$ the presence of iron can significantly reduce the temperature of decarbonation onset and trigger the formation of $\mathrm{CO}_{2}$ fluid and Fe-rich silicates. It should be noted, that phase assemblages of highly ferrous silicates are definitely not representative as mantle rock-forming minerals, they can only demonstrate micro-volumes of mantle, which are in direct contact with carbide. Results of the present study regarding Fe-rich silicates can be useful in a course of reconstruction of the very complex processes of natural rock formation, especially subduction-related or metasomatic.

We suppose that experimentally reproduced decarbonation processes involving carbide or a predominantly metal melt together with accompanying graphite- or diamond-producing redox reactions may occur locally in natural environments, under conditions of oxidized material subduction in a metal-saturated mantle.

\section{Conclusions}

(1) It was experimentally demonstrated that carbide-oxide-carbonate interaction led to decarbonation, with the formation of $\mathrm{Fe}, \mathrm{Mg}$, Ca-garnet and $\mathrm{CO}_{2}$ fluid, and graphite or diamond-producing redox reactions, involving iron carbide, mantle oxidized fluids, melts, carbonates, $\mathrm{Mg}$,Fe silicates and oxides.

(2) Carbide-oxid-carbonate interaction realized in the experiments with $f \mathrm{O}_{2}$-gradient at 7.5 GPa and $1250-1350{ }^{\circ} \mathrm{C}$ resulted in the crystallization of magnesiowüstite + garnet + graphite \pm cohenite assemblage. Graphite under reduced conditions was produced through the redox interactions of carbide with carbonate or $\mathrm{CO}_{2}$, and, under the oxidized conditions, as a result of the redox reaction of magnesiowüstite and $\mathrm{CO}_{2}$. At $1450-1650{ }^{\circ} \mathrm{C}$, carbide-oxide-carbonate interactions resulted in the formation of $\mathrm{Fe}^{3+}$-magnesiowüstite $+\mathrm{Fe}^{3+}$-garnet + graphite assemblage as well as generation of $\mathrm{Fe}^{2+, 3+}$-rich carbonate-silicate melt. This melt, saturated with carbon, acted as a medium of graphite crystallization and diamond growth on seeds.

(3) The experiments without $f \mathrm{O}_{2}$-gradient at $6.3 \mathrm{GPa}$ demonstrated that carbide-oxide-carbonate interaction was accompanied by decarbonation reactions with the formation of $\mathrm{Fe}, \mathrm{Mg}$, $\mathrm{Ca}$-silicates and $\mathrm{CO}_{2}$ fluid as well as by carbon-producing redox reactions between the $\mathrm{CO}_{2}$ fluid and cohenite. These processes resulted in the formation of $\mathrm{Fe}^{2+}, \mathrm{Fe}^{3+}, \mathrm{Mg}$-silicate + magnetite + graphite assemblages $\left(1100-1200^{\circ} \mathrm{C}\right)$ and $\mathrm{Fe}^{3+}$-bearing garnet + orthopyroxene + graphite ( \pm diamond growth) $\left(1300-1500{ }^{\circ} \mathrm{C}\right)$.

(4) Potential mechanisms for crystallization of graphite or diamond during the carbide-oxide-carbonate interaction are oxidation of cohenite by $\mathrm{CO}_{2}$ fluid or carbonate-silicate melt to $\mathrm{FeO}$ and $\mathrm{Fe}_{2} \mathrm{O}_{3}$, which is accompanied by carbon extraction from $\mathrm{Fe}_{3} \mathrm{C}$ and corresponding reduction of $\mathrm{CO}_{2}$ or carbonate component of the melt to $\mathrm{C}^{0}$.

Author Contributions: Conceptualization, Y.B. (Yuliya Bataleva) and Y.P.; Data curation, Y.B. (Yuliya Bataleva) and Y.P.; Formal analysis, Y.B. (Yuliya Bataleva), I.N. and O.B.; Investigation, Y.B. (Yuliya Bataleva), Y.P. and Y.B. (Yuri Borzdov); Methodology, Y.B. (Yuri Borzdov); Visualization, Y.B. (Yuliya Bataleva); Writing-original draft, Y.B. (Yuliya Bataleva); Writing—review \& editing, Y.B. (Yuliya Bataleva) and Y.P.

Funding: This work was supported by the Russian Foundation for Basic Research (project No. 16-35-60024) and a State Assignment (project No. 0330-2016-0007) and the Russian Science Foundation (grant No. 16-17-10041). 
Acknowledgments: The authors express their sincere thanks to the in-house Editor, the guest Academic Editor, and three anonymous Reviewers for helpful and constructive reviews. The authors thank S. Ovchinnikov for his assistance in implementation of Mössbauer spectroscopy measurements and A. Moskalev for his assistance in the work preparation.

Conflicts of Interest: The authors declare no conflict of interest.

\section{References}

1. Luth, R.W.; Virgo, D.; Boyd, F.R.; Wood, B.J. Ferric iron in mantle derived garnets: Implications for thermo-barometry and for the oxidation state of the mantle. Contrib. Mineral. Petrol. 1990, 104, 56-72. [CrossRef]

2. Luth, R.W. Carbon and carbonates in mantle. In Mantle Petrology: Field Observation and High Pressure Experimentation: A Tribute to Francis R. (Joe) Boyd; Fei, Y., Bertka, M.C., Mysen, B.O., Eds.; The Geochemical Society: Washington, DC, USA, 1999; pp. 297-316. ISBN 0-941809-05-6.

3. Frost, D.J.; Liebske, C.; Langenhorst, F.; McCammon, C.A. Experimental evidence for the existence of iron-rich metal in the Earth's lower mantle. Nature 2004, 428, 409-412. [CrossRef] [PubMed]

4. Frost, D.J.; McCammon, C.A. The redox state of Earth's mantle. Annu. Rev. Earth Planet. Sci. 2008, 36, 389-420. [CrossRef]

5. Woodland, A.B.; Koch, M. Variation in oxygen fugacity with depth in the upper mantle beneath the Kaapvaal craton, Southern Africa. Earth Planet. Sci. Lett. 2003, 214, 295-310. [CrossRef]

6. Rohrbach, A.; Ballhaus, C.; Golla-Schindler, U.; Ulmer, P.; Kamenetsky, V.S.; Kuzmin, D.V. Metal saturation in the upper mantle. Nature 2007, 449, 456-458. [CrossRef] [PubMed]

7. Rohrbach, A.; Schmidt, M.W. Redox freezing and melting in the Earth's deep mantle resulting from carbon-iron redox coupling. Nature 2007, 472, 209-212. [CrossRef] [PubMed]

8. Stagno, V.; Tange, Y.; Miyajima, N.; McCammon, C.A.; Irifune, T.; Frost, D.J. The stability of magnesite in the transition zone and the lower mantle as function of oxygen fugacity. Geophys. Res. Lett. 2011, 38, 1-5. [CrossRef]

9. Dasgupta, R.; Hirschmann, M.M. The deep carbon cycle and melting in Earth's interior. Earth Planet. Sci. Lett. 2010, 298, 1-13. [CrossRef]

10. Marty, B. The origins and concentrations of water, carbon, nitrogen and noble gases on Earth. Earth Planet. Sci. Lett. 2012, 313-314, 56-66. [CrossRef]

11. Garber, J.M.; Maurya, S.; Hernandez, J.A.; Duncan, M.S.; Zeng, L.; Zhang, H.L.; Faul, U.; McCammon, C.; Montagner, J.P.; Moresi, L.; et al. Multidisciplinary constraints on the abundance of diamond and eclogite in the cratonic lithosphere. Geochem. Geophys. Geosyst. 2018, 19, 2062-2086. [CrossRef]

12. Lord, O.T.; Walter, M.J.; Dasgupta, R.; Walker, D.; Clark, S.M. Melting in the Fe-C system to 70 GPa. Earth Planet. Sci. Lett. 2009, 284, 157-167. [CrossRef]

13. Sharp, W.E. Pyrrhotite, a common inclusion in South African diamonds. Nature 1966, 21, 402-403. [CrossRef]

14. Torsvik, T.K.; Burke, K.; Steinberger, B.; Webb, S.J.; Ashwal, L.D. Diamonds sampled by plumes from the core-mantle boundary. Nature 2010, 466, 253-357. [CrossRef] [PubMed]

15. Kaminsky, F.V.; Wirth, R. Iron carbide inclusions in lower-mantle diamond from Juina, Brazil. Can. Mineral. 2011, 49, 555-572. [CrossRef]

16. Smith, E.M.; Kopylova, M.G. Implications of metallic iron for diamonds and nitrogen in the sublithospheric mantle. Can. J. Earth Sci. 2014, 51, 510-516. [CrossRef]

17. Smith, E.M.; Shirey, S.B.; Nestola, F.; Bullock, E.S.; Wang, J.; Richardson, S.H.; Wang, W. Large gem diamonds from metallic liquid in Earth's deep mantle. Science 2016, 354, 1403-1405. [CrossRef] [PubMed]

18. Palyanov, Y.N.; Bataleva, Y.V.; Sokol, A.G.; Borzdov, Y.M.; Kupriyanov, I.N.; Reutsky, V.N.; Sobolev, N.V. Mantle-slab interaction and redox mechanism of diamond formation. Proc. Natl. Acad. Sci. USA 2013, 110, 20408-20413. [CrossRef] [PubMed]

19. Rohrbach, A.; Ghosh, S.; Schmidt, M.W.; Wijbrans, C.H.; Klemme, S. The stability of Fe-Ni carbides in the Earth's mantle: Evidence for a low Fe-Ni-C melt fraction in the deep mantle. Earth Planet. Sci. Lett. 2014, 388, 211-221. [CrossRef] 
20. Bataleva, Y.V.; Palyanov, Y.N.; Borzdov, Y.M.; Bayukov, O.A.; Zdrokov, E.V. Iron carbide as a source of carbon for graphite and diamond formation under lithospheric mantle P-T parameters. Lithos 2017, 286-287, 151-161. [CrossRef]

21. Dasgupta, R. Ingassing, storage, and outgassing of terrestrial carbon through geologic time. Rev. Mineral. Geochem. 2013, 75, 183-229. [CrossRef]

22. Harte, B.; Richardson, S.H. Mineral inclusions in diamonds track the evolution of a Mesozoic subducted slab beneath West Gondwanaland. Gondwana Res. 2012, 21, 236-245. [CrossRef]

23. Shirey, S.B.; Cartigny, P.; Frost, D.G.; Keshav, S.; Nestola, F.; Nimis, P.; Pearson, D.G.; Sobolev, N.V.; Walter, M.J. Diamonds and the geology of mantle carbon. Rev. Mineral. Geochem. 2013, 75, 355-421. [CrossRef]

24. Creighton, S.; Stachel, T.; Matveev, S.; Höfer, H.; McCammon, C.; Luth, R.W. Oxidation of the Kaapvaal lithospheric mantle driven by metasomatism. Contrib. Mineral. Petrol. 2009, 157, 491-504. [CrossRef]

25. Kogarko, L.N. Alkaline magmatism and enriched mantle reservoirs: Mechanisms, time, and depth of formation. Geochem. Int. 2006, 44, 3-10. [CrossRef]

26. Malaspina, N.; Scambelluri, M.; Poli, S.; van Roermund, H.L.M.; Langenhorst, F. The oxidation state of mantle wedge majoritic garnet websterites metasomatised by C-bearing subduction fluids. Earth Planet. Sci. Lett. 2010, 298, 417-426. [CrossRef]

27. Ryabchikov, I.D. Mechanisms of diamond formation: Reduction of carbonates or partial oxidation of hydrocarbons. Dokl. Earth Sci. 2009, 429, 1346-1349. [CrossRef]

28. Ryabchikov, I.D.; Kogarko, L.N. Redox potential of mantle magmatic systems. Petrology 2010, 18, $239-251$. [CrossRef]

29. Jacob, D.E.; Kronz, A.; Viljoen, K.S. Cohenite, native iron and troilite inclusions in garnets from polycrystalline diamonds aggregates. Contrib. Mineral. Petrol. 2004, 146, 566-576. [CrossRef]

30. Sobolev, N.V.; Efimova, E.S.; Pospelova, L.N. Native iron in diamonds of Yakutia and its paragenesis. Sov. Geol. Geophys. 1981, 22, 18-21.

31. Stachel, T.; Harris, J.W.; Brey, G.P. Rare and unusual mineral inclusions in diamonds from Mwadui, Tanzania: Contrib. Mineral. Petrol. 1998, 132, 34-47. [CrossRef]

32. Boulard, E.; Gloter, A.; Corgne, A.; Antonangeli, D.; Auzende, A.-L.; Perrillat, J.-P.; Guyot, F.; Fiquet, G. New host for carbon in the deep Earth. Proc. Natl. Acad. Sci. USA 2011, 10, 5184-5187. [CrossRef] [PubMed]

33. Haggerty, S.E. Upper mantle mineralogy. J. Geodyn. 1995, 20, 331-364. [CrossRef]

34. Harris, J.W. Diamond geology. In Properties of Natural and Synthetic Diamond; Field, J.E., Ed.; Academic Press: London, UK, 1992; pp. 345-393. ISBN 9780122553523.

35. Sobolev, N.V. Deep-Seated Inclusions in Kimberlites and the Problem of the Composition of the Upper Mantle, 1st ed.; Nauka: Novosibirsk, Russia, 1974; 264p. (In Russian)

36. Schrauder, M.; Navon, O. Solid carbon dioxide in natural diamond. Nature 1993, 365, 42-44. [CrossRef]

37. Wang, A.; Pasteris, J.D.; Meyer, H.O.A.; DeleDuboi, M.L. Magnesite-bearing inclusion assemblage in natural diamond. Earth Planet. Sci. Lett. 1996, 141, 293-306. [CrossRef]

38. Burnham, A.D.; Thomson, A.R.; Bulanova, G.P.; Kohn, S.C.; Smith, C.B.; Walter, M.J. Stable isotope evidence for crustal recycling as recorded by superdeep diamonds. Earth Planet. Sci. Lett. 2015, 432, 374-380. [CrossRef]

39. Dasgupta, R.; Buono, A.; Whelan, G.; Walker, D. High-pressure melting relations in Fe-C-S systems: Implications for formation, evolution, and structure of metallic cores in planetary bodies: Geochim. Cosmochim. Acta 2009, 73, 6678-6691. [CrossRef]

40. Deng, L.; Fei, Y.; Liu, X.; Gong, Z.; Shahar, A. Effect of carbon, sulfur and silicon on iron melting at high pressure: Implications for composition and evolution of the planetary terrestrial cores. Geochim. Cosmochim. Acta 2013, 114, 220-233. [CrossRef]

41. Tsuno, K.; Dasgupta, R. Fe-Ni-Cu-C-S phase relations at high pressures and temperatures-The role of sulfur in carbon storage and diamond stability at mid-to deep-upper mantle. Earth Planet. Sci. Lett. 2015, 412, 132-142. [CrossRef]

42. Bataleva, Y.V.; Palyanov, Y.N.; Borzdov, Y.M.; Bayukov, O.A.; Sobolev, N.V. Interaction of iron carbide and sulfur under P-T conditions of the lithospheric mantle. Dokl. Earth Sci. 2015, 463, 707-711. [CrossRef]

43. Bataleva, Y.V.; Palyanov, Y.N.; Borzdov, Y.M.; Bayukov, O.A.; Sobolev, N.V. Conditions for diamond and graphite formation from iron carbide at the P-T parameters of lithospheric mantle. Russ. Geol. Geophys. 2016, 57, 176-189. [CrossRef] 
44. Palyanov, Y.N.; Borzdov, Y.M.; Khokhryakov, A.F.; Kupriyanov, I.N.; Sokol, A.G. Effect of nitrogen impurity on diamond crystal growth processes. Cryst. Growth Des. 2010, 10, 3169-3175. [CrossRef]

45. Pal'yanov, Y.N.; Sokol, A.G.; Borzdov, Y.M.; Khokhryakov, A.F. Fluid-bearing alkaline carbonate melts as the medium for the formation of diamonds in the Earth's mantle: An experimental study. Lithos 2002, 60, 145-159. [CrossRef]

46. Sokol, A.G.; Borzdov, Y.M.; Palyanov, Y.N.; Khokhryakov, A.F. High-temperature calibration of a multi-anvil high pressure apparatus. High Press. Res. 2015, 35, 139-147. [CrossRef]

47. Palyanov, Y.N.; Borzdov, Y.M.; Bataleva, Y.V.; Sokol, A.G.; Palyanova, G.A.; Kupriyanov, I.N. Reducing role of sulfides and diamond formation in the Earth's mantle: Earth Planet. Sci. Lett. 2007, 260, 242-256. [CrossRef]

48. Bataleva, Y.V.; Palyanov, Y.N.; Sokol, A.G.; Borzdov, Y.M.; Bayukov, O.A. The role of rocks saturated with metallic iron in the formation of ferric carbonate-silicate melts: Experimental modeling under PT-conditions of lithospheric mantle. Russ. Geol. Geophys. 2015, 56, 143-154. [CrossRef]

49. Bataleva, Y.V.; Palyanov, Y.N.; Borzdov, Y.M.; Kupriyanov, I.N.; Sokol, A.G. Synthesis of diamonds with mineral, fluid and melt inclusions. Lithos 2016, 265, 292-303. [CrossRef]

50. Bataleva, Y.V.; Palyanov, Y.N.; Sokol, A.G.; Borzdov, Y.M.; Palyanova, G.A. Conditions for the origin of oxidized carbonate-silicate melts: Implications for mantle metasomatism and diamond formation. Lithos 2012, 128-131, 113-125. [CrossRef]

51. Bataleva, Y.V.; Palyanov, Y.N.; Sokol, A.G.; Borzdov, Y.M.; Bayukov, O.A. Wüstite stability in the presence of a $\mathrm{CO}_{2}$-fluid and a carbonate-silicate melt: Implications for the graphite/diamond formation and generation of Fe-rich mantle metasomatic agents. Lithos 2016, 244, 20-29. [CrossRef]

52. Newton, R.C.; Sharp, W.E. Stability of forsterite $+\mathrm{CO}_{2}$ and its bearing on the role of $\mathrm{CO}_{2}$ in the mantle. Earth Planet. Sci. Lett. 1975, 26, 239-244. [CrossRef]

53. Knoche, R.; Sweeney, R.J.; Luth, R.W. Carbonation and decarbonation of eclogites: The role of garnet. Contrib. Mineral. Petrol. 1999, 135, 332-339. [CrossRef]

54. Berman, R.G. Thermobarometry using multi-equilibrium calculations: A new technique with petrologic applications. Can. Mineral. 1991, 29, 833-855.

55. Pal'yanov, Y.N.; Sokol, A.G.; Borzdov, Y.M.; Khokhryakov, A.F.; Sobolev, N.V. Diamond formation through carbonate-silicate interaction. Am. Mineral. 2002, 87, 1009-1013. [CrossRef]

56. Pal'yanov, Y.N.; Sokol, A.G.; Tomilenko, A.A.; Sobolev, N.V. Conditions of diamond formation through carbonate-silicate interaction. Eur. J. Mineral. 2005, 17, 207-214. [CrossRef]

57. Navon, O.; Hutcheon, I.D.; Rossman, G.R.; Wasserburg, G.J. Mantle-derived fluids in diamond micro-inclusions. Nature 1988, 335, 784-789. [CrossRef]

58. Kopylova, M.; Navon, O.; Dubrovinsky, L.; Khachatryan, G. Carbonatitic mineralogy of natural diamond-forming fluids. Earth Planet. Sci. Lett. 2010, 291, 126-137. [CrossRef]

59. Oganov, A.R.; Hemley, R.J.; Hazen, R.M.; Jones, A.P. Structure, bonding and mineralogy of carbon at extreme conditions. Rev. Mineral. Geochem. 2013, 75, 47-77. [CrossRef]

60. Akaishi, M.; Kumar, M.S.D.; Kanda, H.; Yamaoka, S. Formation process of diamond from supercritical $\mathrm{H}_{2} \mathrm{O}-\mathrm{CO}_{2}$ fluid under high pressure and high temperature conditions: Diam. Relat. Mater. 2000, 9, 1945-1950. [CrossRef]

61. Pal'yanov, Y.N.; Sokol, A.G.; Khokhryakov, A.F.; Pal'yanova, G.A.; Borzdov, Y.M.; Sobolev, N.V. Diamond and graphite crystallization in $\mathrm{COH}$ fluid at PT parameters of the natural diamond formation. Dokl. Earth Sci. 2000, 375, 1395-1398.

62. Yamaoka, S.; Akaishi, M.; Kanda, H.; Osawa, T. Crystal growth of diamond in the system of carbon and water under very high pressure and temperature. J. Cryst. Growth 1992, 125, 375-377. [CrossRef]

63. Palyanov, Y.N.; Sokol, A.G.; Khokhryakov, A.F.; Kruk, A.N. Conditions of diamond crystallization in kimberlite melt: Experimental data. Russ. Geol. Geophys. 2015, 56, 196-210. [CrossRef]

64. Palyanov, Y.N.; Shatsky, V.S.; Sokol, A.G.; Tomilenko, A.A.; Sobolev, N.V. Crystallization of metamorphic diamond: An experimental modeling. Dokl. Earth Sci. 2001, 381, 935-938.

65. Palyanov, Y.N.; Khokhryakov, A.F.; Borzdov, Y.M.; Kupriyanov, I.N. Diamond growth and morphology under the influence of impurity adsorption. Cryst. Growth Des. 2013, 13, 5411-5419. [CrossRef] 
66. Brenker, F.E.; Vollmer, C.; Vincze, L.; Vekemans, B.; Szymanski, A.; Janssens, K.; Szaloki, I.; Nasdala, L.; Joswig, W.; Kaminsky, F. Carbonates from the lower part of transition zone or even the lower mantle. Earth Planet. Sci. Lett. 2007, 260, 1-9. [CrossRef]

67. Martin, A.M.; Hammouda, T. Role of iron and reducing conditions on the stability of dolomite + coesite between 4.25 and $6 \mathrm{GPa}-\mathrm{A}$ potential mechanism for diamond formation during subduction. Eur. J. Mineral. 2011, 23, 5-16. [CrossRef] 